Prepared in cooperation with the Massachusetts Office of Coastal Zone Management

Massachusetts Shoreline Change Mapping and Analysis Project, 2013 Update 
THIS PAGE INTENTIONALLY LEFT BLANK 


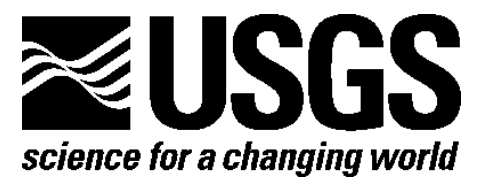

Prepared in cooperation with the Massachusetts Office of Coastal Zone Management

\section{Massachusetts Shoreline Change Mapping and Analysis Project, 2013 Update}

By E. Robert Thieler, Theresa L. Smith, Julia M. Knisel, and Daniel W. Sampson

Open-File Report 2012-1189

U.S. Department of the Interior

U.S. Geological Survey 


\section{U.S. Department of the Interior \\ SALLY JEWELL, Secretary}

\section{U.S. Geological Survey \\ Suzette M. Kimball, Acting Director}

U.S. Geological Survey, Reston, Virginia: 2013

For more information on the USGS-the Federal source for science about the Earth, its natural and living resources, natural hazards, and the environment-visit http://www.usgs.gov or call 1-888-ASK-USGS

For an overview of USGS information products, including maps, imagery, and publications, visit http://www.usgs.gov/pubprod

To order this and other USGS information products, visit http://store.usgs.gov

Any use of trade, firm, or product names is for descriptive purposes only and does not imply endorsement by the U.S. Government.

Although this information product, for the most part, is in the public domain, it also may contain copyrighted materials as noted in the text. Permission to reproduce copyrighted items must be secured from the copyright owner. 


\section{Acknowledgements}

This assessment of historical shoreline change in Massachusetts was undertaken through an agreement between the U.S. Geological Survey (USGS) and the Massachusetts Office of Coastal Zone Management (CZM) with funding from the National Oceanic and Atmospheric Administration. Massachusetts Geographic Information System (MassGIS) personnel provided orthoimagery and metadata.

We thank several people from the USGS Coastal and Marine Geology Program for their support in completing this project. Emily Himmelstoss assisted with estimating uncertainties and writing metadata, helping to calculate rates of shoreline change, and providing technical support. Amy Farris generated the 2007 lidar shoreline data. Jeff List provided technical advice and computed regionally averaged rates and confidence intervals. Meredith Kratzmann suggested improvements for the figures.

We thank Cheryl Hapke and Erika Lentz for their technical reviews of this report. 


\section{Contents}

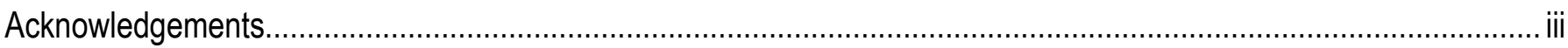

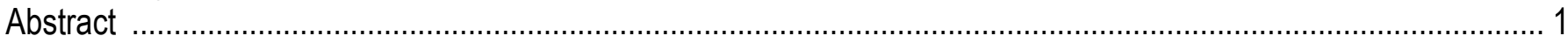

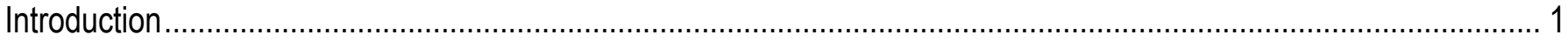

Methods

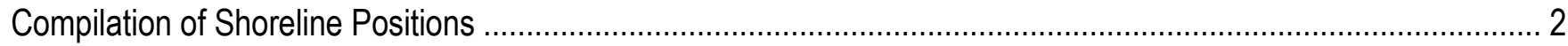



Proxy-Datum Bias Correction Between High Water and Mean High Water Shorelines .......................................... 5



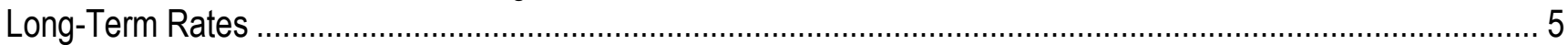



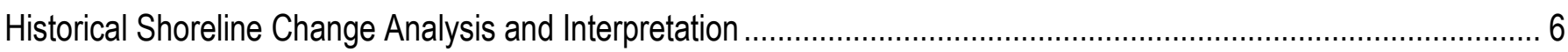

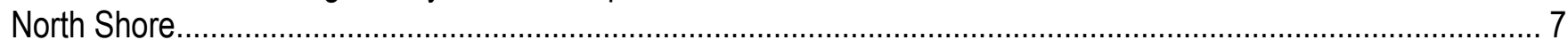

Boston



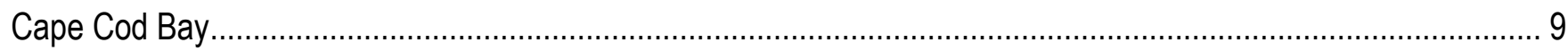



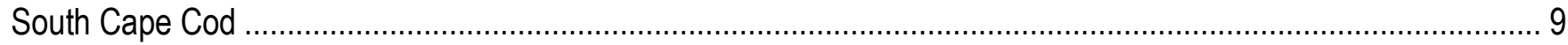

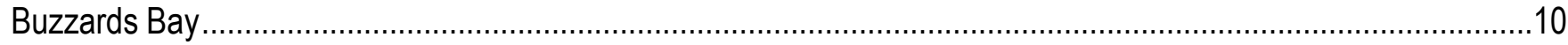

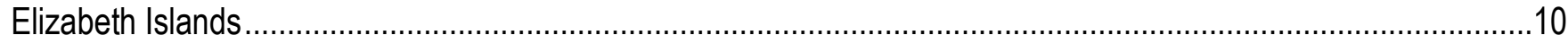

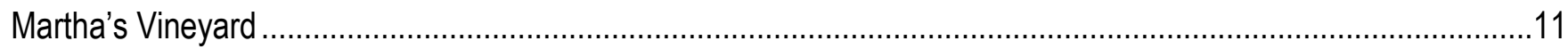

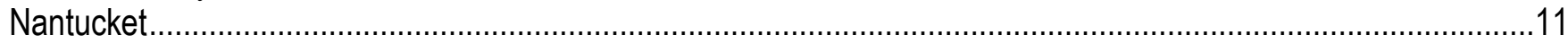

Effect of Shorelines From the 1970s and 1994 on Rates of Shoreline Change ................................................12

Comparison of Rates of Shoreline Change With Previous Studies ...................................................................13

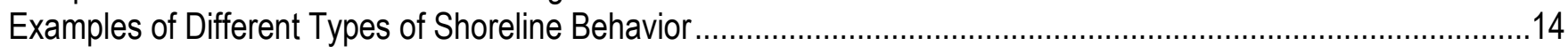

Summary

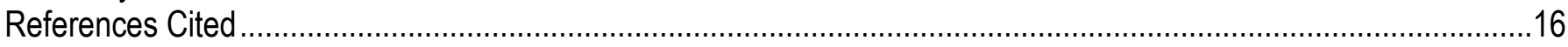

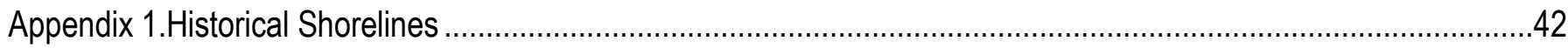

\section{Figures}

1. Index map of the Massachusetts coastline, showing place names mentioned on maps and in text...............19

2. Map showing the spatial extent of new shoreline data produced for this study .........................................20

3. Map showing areas identified as having poor-quality orthophotography from 2009 due principally to image distortions and poor contrast

4. Diagram showing the relation between the measurement baseline, the transects from the Digital Shoreline Analysis System database, shoreline measurement points, and shoreline positional uncertainty ..................22

5. Map and graphs showing long-term linear regression and short-term end-point rates of shoreline change in Massachusetts for the North Shore region ....................................................................................2

6. Map and graphs showing long-term linear regression and short-term end-point rates of shoreline change in Massachusetts for the Boston region............................................................................................

7. Map and graphs showing long-term linear regression and short-term end-point rates of shoreline change in Massachusetts for the South Shore region....................................................................................25

8. Map and graphs showing long-term linear regression and short-term end-point rates of shoreline change in Massachusetts for the Cape Cod Bay region ................................................................................... 26

9. Map and graphs showing long-term linear regression and short-term rates of end-point shoreline change in Massachusetts for the Outer Cape Cod region. 
10. Map and graphs showing long-term linear regression and short-term end-point rates of shoreline change in Massachusetts for the South Cape Cod region

11. Map and graphs showing long-term linear regression and short-term end-point rates of shoreline change in Massachusetts for the Buzzards Bay region.

12. Map and graphs showing long-term linear regression and short-term end-point rates of shoreline change in

Massachusetts for the Elizabeth Islands region.

13. Map and graphs showing long-term linear regression and short-term end-point rates of shoreline change in Massachusetts for the Martha's Vineyard region

14. Map and graphs showing long-term linear regression and short-term end-point rates of shoreline change in Massachusetts for the Nantucket region.

15. Map showing the spatial extent of historical shoreline data for the coast of Massachusetts compared with the data used in the 2010 national assessment of shoreline change

16. Orthophotograph and historical shorelines showing a unidirectional long-term trend of shoreline change at transect 769 on the southern coast of Nantucket, Massachusetts.

17. Orthophotograph and historical shorelines showing a unidirectional long-term trend of shoreline change at transect 899 on a barrier spit near Osterville, Massachusetts

18. Orthophotograph and historical shorelines showing a fluctuating history of shoreline change at transect 899 on a sandy beach in Brewster, Massachusetts.

19. Orthophotograph and historical shorelines showing a landward constraint on shoreline movement due to a seawall at transect 1745 in Marshfield, Massachusetts.

20. Orthophotograph and historical shorelines showing significant artificial seaward shoreline movement due to human activities at transect 33 at Carson Beach, Massachusetts.....

\section{Tables}

1. Lengths of shoreline indicators alongshore used to delineate new shorelines in Massachusetts

2. Measurements of uncertainty for the regions used to calculate rates of shoreline change in Massachusetts .39

3. Maximum statistically significant rates of shoreline change in Massachusetts

4. Long-term linear regression rates of shoreline change in Massachusetts

5. Long-term linear regression rates of shoreline change in Massachusetts calculated by this study and by Hapke and others (2010) 


\section{Conversion Factors, Datums, and Abbreviations}

SI to Inch/Pound

\begin{tabular}{lll}
\hline \multicolumn{1}{c}{ Multiply } & \multicolumn{1}{c}{ By } & \multicolumn{1}{c}{ To obtain } \\
\hline & Length & \\
\hline centimeter $(\mathrm{cm})$ & 0.3937 & inch (in.) \\
meter $(\mathrm{m})$ & 3.281 & foot (ft) \\
kilometer $(\mathrm{km})$ & 0.6214 & mile (mi) \\
kilometer $(\mathrm{km})$ & 0.5400 & mile, nautical (nmi) \\
meter $(\mathrm{m})$ & 1.094 & yard (yd) \\
\hline
\end{tabular}

Vertical coordinate information is referenced to the North American Vertical Datum of 1988 (NAVD 88).

Horizontal coordinate information is referenced to the North American Datum of 1983 (NAD 83).

Elevation, as used in this report, refers to distance above the vertical datum.

\section{Abbreviations}

CZM Coastal Zone Management

DSAS Digital Shoreline Analysis System

HWL high water line

LTW long-term weighted

MassGIS Massachusetts Geographic Information System

MHW mean high water

NOAA National Oceanic and Atmospheric Administration

RMS root mean square

USACE U.S. Army Corps of Engineers

USGS U.S. Geological Survey

WLR weighted linear regression 


\title{
Massachusetts Shoreline Change Mapping and Analysis Project, 2013 Update
}

\author{
By E. Robert Thieler, Theresa L. Smith, Julia M. Knisel, and Daniel W. Sampson
}

\begin{abstract}
Information on rates and trends of shoreline change can be used to improve the understanding of the underlying causes and potential effects of coastal erosion on coastal populations and infrastructure and can support informed coastal management decisions. In this report, we summarize the changes in the historical positions of the shoreline of the Massachusetts coast for the 165 years from 1844 through 2009. The study area includes the Massachusetts coastal region from Salisbury to Westport, including Cape Cod, as well as Martha's Vineyard, Nantucket, and the Elizabeth Islands. New statewide shoreline data were developed for approximately 1,804 kilometers (1,121 miles) of shoreline using color aerial orthoimagery from 2008 and 2009 and topographic lidar from 2007.

The shoreline data were integrated with existing historical shoreline data from the U.S. Geological Survey (USGS) and Massachusetts Office of Coastal Zone Management (CZM) to compute long- (about 150 years) and short-term (about 30 years) rates of shoreline change. A linear regression method was used to calculate long- and short-term rates of shoreline change at 26,510 transects along the Massachusetts coast. In locations where shoreline data were insufficient to use the linear regression method, short-term rates were calculated using an end-point method.

Long-term rates of shoreline change are calculated with (LTw) and without (LTwo) shorelines from the 1970s and 1994 to examine the effect of removing these data on measured rates of change. Regionally averaged rates are used to assess the general characteristics of the two-rate computations, and we find that (1) the rates of change for both LTw and LTwo are essentially the same; (2) including more data slightly reduces the uncertainty of the rate, which is expected as the number of shorelines increases; and (3) the data for the shorelines from the 1970s and 1994 are not outliers with respect to the long-term trend. These findings are true for regional averages, but may not hold at specific transects.
\end{abstract}

\section{Introduction}

The Commonwealth of Massachusetts coastal zone has a broad base of natural and economic resources in which tourism, shipping, and commercial fishing industries constitute an important part of the economy of the Commonwealth. Coastal areas are dynamic in nature: changes such as shoreline erosion and accretion occur over many time scales. The coastal zone is also the site of high-density residential and commercial development. As coastal population growth continues, natural hazards such as shoreline erosion, flooding, and storm effects can have an increasing influence on coastal communities and economies. For these reasons, shoreline change analysis has become a common objective of coastal management programs (Morton, 1991; Thieler and Danforth, 1994; Moore, 2000).

In 1989, the Massachusetts Office of Coastal Zone Management (CZM) initiated the Shoreline Change Project to identify erosion-prone areas of the coast. Historical shoreline positions along the 
coast of Massachusetts (fig. 1) were delineated from paper maps and aerial photographs from the mid1800s to 1978 and compiled into a GIS compatible format (Benoit, 1989). The project was updated when new data became available and improved statistical techniques for calculating rates of shoreline change were developed. In 1996, a digitally computed statistical analysis of shoreline change was completed by Applied Geographics, Inc. (O’Connell, 1997; Van Dusen, 1997) using a modified version of the U.S. Geological Survey (USGS) Digital Shoreline Analysis System version 1.0 (DSAS; Danforth and Thieler, 1992). In 2001, a shoreline for 1994 digitized from 1-meter (m)-resolution orthophotographs was added to the CZM historical shoreline database, and long-term linear regression (for data from 1844 through 1994) and short-term end-point (for data from the 1970s through 1994) rates of shoreline change were calculated for the Commonwealth (Thieler and others, 2001). In 2006, the CZM contracted with Applied Coastal Research and Engineering, Inc. (Applied Coastal) to delineate a 2001 shoreline from $0.5-\mathrm{m}$ resolution orthophotographs and calculate rates of shoreline change for the South Shore region from Hull to the Cape Cod Canal. Shorelines from these previous studies are available from the Massachusetts Ocean Resource Information System (MORIS; http://www.mass.gov/czm/mapping/index.htm).

For this report, historical shorelines from the mid-1800s to 2001 were compiled from previous CZM studies as well as recent USGS work (Himmelstoss and others, 2010) along predominantly openwater-facing sections of the Massachusetts coast (appendix 1). New shorelines (fig. 2) of about $1,804 \mathrm{~km}$ (1,121 miles) were delineated for Massachusetts using color orthoimagery for 2008 and 2009 from the USGS and extracted from topographic lidar data for 2007 obtained from the U.S. Army Corps of Engineers (USACE). The new shorelines were integrated with existing CZM and USGS historical shoreline data, and DSAS version 4.0 was used in Environmental Systems and Research Institute, Inc. (Esri) ArcGIS version 9.3 to calculate long- and short-term rates of shoreline change. The total number of historical shorelines used to estimate rates of change along the coast generally ranges from four to seven, with a minimum of two and a maximum of eight.

This report provides updated delineations of shorelines and rates of shoreline change for the coastal shoreline of Massachusetts. In this report, we (1) summarize the methods used to compile historical shorelines, delineate the 2007, 2008, and 2009 shorelines, evaluate errors and uncertainty associated with each data source, and calculate rates of shoreline change; (2) provide an overview of the results for each region to facilitate the interpretation and use of the shoreline change data; and (3) compare regionally averaged rates of shoreline change in this report to a dataset with a reduced number of shorelines and to a recent compilation (Himmelstoss and others, 2010) of rates of shoreline change for some of the Massachusetts sandy ocean shoreline.

\section{Methods}

In this section, we describe the methods used to compile and delineate the shorelines used in this report, quantify their positional uncertainty, correct for biases between shorelines that delineate different shoreline proxies, and estimate rates of shoreline change.

\section{Compilation of Shoreline Positions}

Data from before 2007.- Shorelines for the mid-1800s to 1994 are derived primarily from National Oceanic and Atmospheric Administration (NOAA) topographic map sheets (T-sheets) and aerial photographs that were obtained from the CZM (Thieler and others, 2001) and the USGS (Himmelstoss and others, 2010). The shorelines cover the Massachusetts coastal region from Salisbury to Westport, including Cape Cod, the Elizabeth Islands, Martha's Vineyard, and Nantucket. Data for a 
lidar-derived shoreline in 2000 covering most of the ocean-facing coastline of Massachusetts was also obtained from the USGS (Himmelstoss and others, 2010). In addition, the CZM provided a shoreline digitized by Applied Coastal from 50-centimeter (cm)-resolution color orthophotographs collected during aerial photography missions in April 2001that cover sections of the coast from Nantasket Beach to the Cape Cod Canal (the South Shore study region; Applied Coastal Research and Engineering, Inc., 2006). The total number of historical shorelines used to estimate rates of change at any given location along the Massachusetts coast generally ranges from four to seven.

Lidar from 2007. - An operational mean high water (MHW) shoreline was derived from lidar surveys collected by the USACE in 2007 following methods in Stockdon and others (2002). This approach converts the lidar orthometric datum to a MHW datum using data compiled by Weber and others (2005). This methodology is also used in other USGS shoreline change assessments nationwide (http://coastal.er.usgs.gov/shoreline-change/), including Hapke and others (2011) and Himmelstoss and others (2010), which cover Massachusetts. A positional uncertainty associated with each shoreline point was computed following Stockdon and others (2002) and is described in the Estimation of Shoreline Position Uncertainty section.

Orthophotographs from 2008 and 2009. - Vector shorelines representing the local high water line (HWL) were digitized from 15- and 30-cm resolution, four-band (natural red, green, and blue and infrared) color orthophotographs using the sketch tool in Esri ArcEditor/ArcMap version 9.3. The shorelines were digitized at a scale of 1:300 for the $15-\mathrm{cm}$ and 1:500 for the $30-\mathrm{cm}$ orthophotographs. These scales were found to reasonably balance image pixel size representation on a computer monitor and the ability of the interpreter to identify the shoreline indicator (for example, high water mark or tonal change across rocky or sandy coast).

The HWL shoreline is recognized as the landward limit of wave runup at the time of local high tide. The HWL was delineated using the following indicators as proxies for the high water line, after Thieler and others (2001) and Boak and Turner (2005): (1) the previous high tide line seaward of the storm debris wrack line, as indicated by the tonal changes between wet and dry beach material (that is, sand, gravel, cobble), a seaweed or debris line, or a combination of both; (2) the high-tide wrack line, created when the high tide deposits seaweed and debris on the upper beach; (3) the vegetation change between Spartina patens (saltmeadow cordgrass) in the high marsh zone and Spartina alterniflora (smooth cordgrass or saltmarsh cordgrass) in the low marsh zone (Bertness, 1991) or the outer limits of emergent marsh vegetation (when vegetation types were not discernible); (4) the algal line on rocky outcrops, indicated by the tonal change between wet surfaces that host algae and dry surfaces with no algae; (5) the maximum wave runup limit at or near high tide indicated by the interface between the land and water ; and (6) the interface between vertical seawalls and bulkheads and open water. The lengths of the coast line characterized by the different shoreline indicators are listed in table 1 .

\section{Estimation of Shoreline Position Uncertainty}

The numerous potential errors involved in the process of calculating rates of shoreline change make it necessary to provide a best estimate of the total positional uncertainty associated with each shoreline position. Uncertainties for HWL shorelines include errors introduced by data sources and errors introduced by measurement methods (Anders and Byrnes, 1991; Crowell and others, 1991; Thieler and Danforth, 1994; Moore, 2000; Ruggiero and others, 2003). The following components (uncertainty terms) were considered when estimating the positional uncertainty for HWL shorelines: (1) georeferencing uncertainty; (2) digitizing uncertainty; (3) T-sheet survey uncertainty; (4) aerial photograph collection and rectification uncertainty; and (5) the uncertainty of the HWL at the time of survey (Crowell and others, 1991). For each HWL shoreline position, the HWL position uncertainty is 
found as the square root of the sum of the squares (Taylor, 1997) of the relevant uncertainty terms, based on an assumption that each term is random and independent of the others (Hapke and others, 2011). The average values for each uncertainty term and the total average positional uncertainty were estimated for each shoreline type (table 2) using methods described in Hapke and others (2011) and in the metadata for previously published Massachusetts shorelines (Himmelstoss and others, 2010).

One component of the total average uncertainty is the uncertainty of the HWL at the time of survey, which is an estimate of the uncertainty in the position of the shoreline resulting from the slope of the beach and water level variations due to waves and tides (Ruggiero and List, 2009). Where one or more lidar surveys are available, the lidar data provide a site-specific estimate of the beach slope. Sitespecific wave and tidal information are derived from wave information studies (U.S. Army Corps of Engineers, 2010) and NOAA tidal datum information (Weber and others, 2005), respectively. The uncertainty in these parameters is used to compute the HWL uncertainty following methods described by Ruggiero and List (2009).

The site-specific HWL uncertainty values are combined with the positional uncertainty for the historic shorelines to compute a total HWL positional uncertainty at each transect following the method described in Himmelstoss (2009, appendix 2). For sections of coast where lidar-derived beach slope data are not available, the average HWL uncertainty ( $\pm 4.3 \mathrm{~m}$; table 2$)$ is combined with the historic shoreline uncertainty. This average value is determined by averaging the HWL uncertainty for regions where a lidar-derived beach slope is available. The values listed in table 2 are used only when sitespecific estimates of the uncertainty in the HWL position are unknown.

Orthophotographs. - The positional uncertainty estimates for shorelines derived from the $15-\mathrm{cm}$ orthophotographs from 2008 and the 30-cm orthophotographs from 2008 and 2009 were calculated from the following components: (1) digitizing error (1.0 m; Hapke and others, 2011), (2) root-mean-square (RMS) error of orthorectification obtained from the source orthophotography $( \pm 0.25 \mathrm{~m}$ for the 15 -cm orthophotographs, and $\pm 2.12 \mathrm{~m}$ for the 30 -cm orthophotographs), and (3) the average HWL uncertainty $( \pm 4.3 \mathrm{~m})$ for the Commonwealth described above. The total positional uncertainty was estimated by combining the three uncertainty components using the square root of the sum of the squares. The statewide average positional uncertainty values are $\pm 4.4 \mathrm{~m}$ for the $15-\mathrm{cm}$ shoreline data from 2008 and $\pm 4.9 \mathrm{~m}$ for the $30-\mathrm{cm}$ shoreline data from 2008 and 2009 (table 2).

Some areas in the orthophotograph dataset from 2009 contained poor-quality imagery (fig. 3), which manifested principally as image distortions and poor contrast. This resulted in the inability to confidently identify the shoreline position. Shorelines digitized in areas with poor-quality imagery were assigned an aerial photograph uncertainty of $\pm 4.23 \mathrm{~m}$ to account for these issues, based on comparisons with other sources of orthophotography.

Lidar.-Determination of positional uncertainty for each lidar-derived MHW (2000 and 2007) shoreline position follows established methods described by Stockdon and others (2002) and Ruggiero and List (2009). The lidar-derived MHW shoreline position uncertainty includes the following components: (1) the 95-percent confidence interval (CI) associated with the regression estimate in the determination of the shoreline position for each cross-shore profile of lidar point cloud data (Stockdon and others, 2002); (2) the uncertainty of the raw lidar data position in which the vertical uncertainty determined by Sallenger and others (2003) is converted to horizontal shoreline position uncertainty using the beach slope as determined by linear regression; and (3) the uncertainty due to extrapolation, which is the difference between an observed position and a position predicted on a projected regression line (Stockdon and others, 2002). The lidar position uncertainty is calculated using the square root of the sum of the squares. This total uncertainty varies on a profile-by-profile basis with a statewide average of $\pm 1.27 \mathrm{~m}$ (table 2). 


\section{Proxy-Datum Bias Correction Between High Water and Mean High Water Shorelines}

Shorelines derived from NOAA T-sheets, aerial photographs, and high-resolution orthophotographs use the HWL as the shoreline proxy. Lidar-derived shorelines, however, are not based on visual criteria but rather on the cross-shore position of an elevation contour extracted from topographic data and are defined on the basis of an elevation or a tidal datum, such as MHW (Smith and Zarillo, 1990; List and Farris, 1999; Stockdon and others, 2002; Leatherman and others, 2003; Robertson and others, 2004; Ruggiero and others, 2005; Moore and others, 2006). Several studies have determined that the proxy-datum bias between HWL and MHW shorelines is a unidirectional offset (or bias) with the HWL position located landward of the MHW position (Ruggiero and others, 1996, 2001, 2003; Morton and others, 2004; Moore and others, 2006; Stockdon and others, 2006; Ruggiero and List, 2009). When this bias is left uncorrected, the proxy-datum offset causes calculated rates of change to show rates of erosion or accretion not indicative of actual shoreline movement or to show trend reversals (for example, from erosion to accretion) that did not actually occur (Ruggiero and List, 2009). Therefore, changing the shoreline definition from a proxy-based physical feature (HWL) to a datumbased shoreline (MHW) is important when inferring changes in shoreline position and calculating rates of change to minimize bias (Ruggiero and List, 2009).

The rates of shoreline change presented in this report apply a proxy-datum bias correction to the data using functionality in the DSAS software tool used to calculate shoreline rates of change (Himmelstoss, 2009, appendix 2). DSAS incorporates a proxy-datum bias value to reconcile the horizontal offsets between the MHW and HWL shoreline proxies described above. The specific methodology used to determine the proxy-datum bias is detailed in Ruggiero and List (2009).

\section{Calculation of Rates of Shoreline Change}

Rates of Long- (about 150 years) and short-term (about 30 years) shoreline change for this study were calculated using DSAS version 4.0, an ArcGIS tool developed by the USGS (Thieler and others, 2009). The tool is a freely available application for ArcGIS. The DSAS uses a measurement baseline method (Leatherman and Clow, 1983) to calculate rate-of-change statistics for a time series of shoreline positions (fig. 4).

The reference baseline serves as the starting point for measurement transects generated by the DSAS software. A new reference baseline was digitized in ArcMap at a scale of 1:10,000. Baselines were placed either onshore (adjacent to the most landward shoreline) or offshore (adjacent to the most seaward shoreline) and positioned to generally parallel the combined orientation of all shorelines. This ensures that measurement transects are perpendicular to the trend of overall shoreline movement through time. Transects were cast at 50-m spacing along the coast.

The transects were visually inspected to check that every transect established an intersection point with each shoreline. These measurement points were then used to perform the rate of change calculations. Transects were removed or moved if they intersected coastal engineering structures such as groins and jetties, extended if they did not intersect one of the shorelines, or repositioned if they were not perpendicular to the general trend of the shoreline data. Transects were modified using standard editing tools in ArcMap by moving or deleting the transects individually or by adjusting the position of the baseline and recasting the transects.

\section{Long-Term Rates}

Long-term rates of shoreline change were determined by fitting a least squares regression line to all shoreline positions from the earliest (mid-1800s) to the most recent $(2007,2008$, or 2009). The rate 
of change is the slope of the regression line. Negative values indicate erosion, and positive values indicate accretion. The calculation of linear regression rates requires a minimum of shoreline data from 3 years at each transect. Long-term rates of shoreline change calculated with many shoreline positions can increase confidence in the data by reducing potential errors associated with the source data, and fluctuating short-term changes (Dolan and others, 1991). For regions that included a lidar shoreline, the proxy-datum bias correction was applied to correct for horizontal offsets between the MHW and HWL proxies.

The linear regression method for determining rates of shoreline change assumes a linear trend of change between the earliest and most recent shoreline dates. However, in locations where rates of shoreline change have not remained constant through time, a linear trend does not exist. For example, a shoreline may exhibit accretion during the first 100 years, but in later years, the shoreline may shift to an erosional trend. In these cases, it is expected that the resulting linear fit to the data is poorer, and the uncertainty of the rate of shoreline change is higher.

\section{Short-Term Rates}

Short-term rates of shoreline change were calculated using the linear regression method for the time interval beginning between 1970 and 1982 and ending between 2000 and 2008 or 2009 . These two time periods define an approximately 30-year span that includes multiple shorelines. Shoreline change that occurs over a short time span can be characterized by cyclic or episodic nonlinear behavior, such as storm-induced shoreline retreat. High short-term variability increases the uncertainty of the rate of shoreline change relative to the linear trend assumed in linear regression calculations. This increases the potential for rates of shoreline change that are statistically insignificant. In many locations, the shortterm trend is calculated with only three to four shorelines. Because uncertainty generally decreases with an increasing number of shoreline data points, the small number of shorelines in the short-term calculation can result in higher uncertainty. To supplement gaps in the short-term data, end-point rates were calculated at each transect that did not intersect the minimum number of three shorelines required to calculate a linear regression rate. Due to the limited availability of data from 1970 to 1982, short-term rates of shoreline change for the Boston and Elizabeth Islands regions were calculated using the endpoint method (except Peddocks Island in the Boston region). With a few exceptions, end-point rates for all regions were calculated using the 1994 to 2008 or 2009 timespan, or about 14 to 15 years. For regions where a lidar shoreline was used in the rate calculation, the proxy-datum bias correction was applied to correct for horizontal offsets between the MHW and HWL proxies.

End-point rates are reported in locations where there are insufficient data to use the linear regression method. The end-point rate is calculated by dividing the distance between shorelines by the time elapsed between the oldest and the most recent shoreline. End-point rates represent the net change between the two shorelines divided by the elapsed time period. Unlike the linear regression method, end-point rates do not have an associated expression (such as a confidence interval) of how scattered the shoreline positions are relative to an assumed linear trend.

\section{Historical Shoreline Change Analysis and Interpretation}

Shorelines are continuously moving in response to winds, waves, tides, sediment supply, changes in relative sea level, and human activities. Shoreline changes are not constant through time and frequently switch from negative (erosion) to positive (accretion) and vice versa. Cyclic and noncyclic processes change the position of the shoreline over a variety of timescales, from the daily and seasonal effects of winds and waves, to changes in sea level over a century to thousands of years. The shoreline 
"rate of change" statistic thus reflects a cumulative summary of the processes that altered the shoreline for the time period analyzed.

This section summarizes the results of shoreline change analysis of the Massachusetts coastline. Shoreline rates of change are summarized for Massachusetts by dividing the coast into 10 geographic regions (fig. 1). The regions are North Shore, Boston, South Shore, Cape Cod Bay, Outer Cape Cod, South Cape Cod, Buzzards Bay, Elizabeth Islands, Martha's Vineyard, and Nantucket. These regions differ slightly from the administrative regions defined by CZM regional offices

(http://www.mass.gov/czm/regions.htm). The maximum erosion and accretion rates presented in this report (table 3) are the highest rates that are statistically significant for each region, as determined by selecting the highest rate within each region that had a value greater than the uncertainty defined by the 90-percent confidence interval.

\section{North Shore}

The North Shore region extends from Salisbury at the New Hampshire border to the western side of Deer Island in Boston Harbor (fig. 5). The northern part of the region, from Salisbury to Cape Ann, is dominated by sandy barrier islands, including Salisbury Beach and Plum Island. Following the coastal development classification system of Hapke and others (2011), the coastline in this region ranges from moderately to highly developed. Coastal engineering structures include groins and jetties at the mouth of the Merrimack River in Newburyport. The southern part of the region is dominated by rocky coastline with small pocket beaches between headlands and by urbanized coastline in the more densely populated areas such as Beverly, Gloucester, Lynn, and Winthrop. Beaches in these population centers are frequently armored with seawalls, riprap revetments, groins, and breakwaters. Beaches throughout the region, such as those on Plum Island, Revere Beach, and Winthrop Beach, have a history of beach nourishment (Western Carolina University, 2012).

Long-term rates of shoreline change (fig. 5) for the North Shore were calculated for 3,932 transects along approximately $224 \mathrm{~km}$ (139 miles) of shoreline. The most dynamic section of the region is the system of barrier islands and beaches from Salisbury to Cape Ann that includes Salisbury Beach, Plum Island, and Castle Neck. The maximum long-term erosion rate $(-1.7 \pm 0.7 \mathrm{~m} / \mathrm{yr})$ occurred on the western side of Plum Island, facing the Parker River (table 3). The average long-term rate of shoreline change for Plum Island from the Merrimack River to Sandy Point was $-0.09 \pm 0.6 \mathrm{~m} / \mathrm{yr}$, which is not a statistically significant trend and reflects the mobility of this beach system. The long-term maximum accretion rate of $2.7 \pm 2.1 \mathrm{~m} / \mathrm{yr}$ occurred at Sandy Point (Plum Island), at the end of a spit that extends into the mouth of the Parker River.

Short-term linear regression rates of change for the North Shore region were calculated for 2,505 transects along $223 \mathrm{~km}$ (139 miles) of shoreline. Because of a lack of historical data on shorelines in this area since the 1970s, not all transects intersected the minimum of three shorelines required to compute linear regression statistics. To supplement gaps in the short-term data, end-point rates were calculated for 1,427 transects for 1994 to 2008 (fig. 5). The maximum short-term linear regression erosion rate $(-16.3 \pm 12.8 \mathrm{~m} / \mathrm{yr})$ occurred at Sandy Point, near the location of the long-term maximum erosion rate. The highest short-term accretion rate $(5.0 \pm 3.9 \mathrm{~m} / \mathrm{yr})$ was measured on Plum Island at the entrance to the Merrimack River, northwest of the jetty. The average short-term rate for Plum Island from the Merrimack River to Sandy Point was $-0.93 \pm 3.1 \mathrm{~m} / \mathrm{yr}$, which also is not statistically significant.

\section{Boston}

The Boston region extends from Carson Beach in South Boston to the Weymouth River, and includes the Boston Harbor Islands (fig. 6). The mainland coastline in this region is moderately to 
densely developed (Hapke and others, 2011), with tourist and commercial infrastructure. Seawalls and revetments frequently occur along the mainland beaches. Consistent with previous studies on shoreline change in Massachusetts (Benoit, 1989; O'Connell, 1997; Thieler and others, 2001), areas of heavily developed coastline in the city of Boston were not included in rates of shoreline change calculations, principally because there has been no shoreline movement in areas dominated by permanent, fixed structures. Geomorphology in this region includes rocky outcrops interspersed with pocket beaches and sandy ocean-facing beaches that are nourished with dredged material (Western Carolina University, 2012), mud flats, and poorly developed salt marshes. The Boston Harbor Islands are dominated by a partially submerged drumlin field deposited during the late Pleistocene glaciation of this area. A few of the outer islands are underlain by bedrock.

Long-term rates of shoreline change (fig. 6) for Boston are based on 1,295 transects covering approximately $112 \mathrm{~km}$ (70 miles) of coastline. The highest rate of erosion $-1.5 \pm 0.09 \mathrm{~m} / \mathrm{yr}$, was found at Lovells Island in Boston Harbor downdrift of a groin field and a breakwater running parallel to the shoreline. The maximum accretion rate was $2.6 \pm 0.8 \mathrm{~m} / \mathrm{yr}$ measured at Columbia Point, east of Carson Beach where some of the harbor was filled in for development.

Short-term rates were measured at 1,160 transects along approximately $112 \mathrm{~km}$ (70 miles) of shoreline. Due to a lack of historical shorelines, the end-point statistic was used to calculate rates for 1994 to 2008. Linear regression rates were calculated only for Peddocks Island (fig. 6). The maximum erosion end-point rate of $-7.7 \mathrm{~m} / \mathrm{yr}$ was measured in mud flats southwest of Nickerson Beach. The maximum end-point accretion rate, located west of Nickerson Beach in Quincy, was $4.7 \mathrm{~m} / \mathrm{yr}$.

\section{South Shore}

The South Shore region extends from the Weymouth River to Scusset Beach on the western side of the Cape Cod Canal (fig. 7). The geomorphology of the region's coast varies, with headland beaches consisting of consolidated till fronted by boulders, tall glacial coastal banks with narrow linear beaches, rocky outcrops interspersed with pocket beaches, and long barrier spits that extend across bays or estuaries. Because most of the coastline faces the east, the South Shore is exposed to the storm winds from the north and northeast, and particularly extratropical storms (nor'easters) that occur during the fall and winter months. The South Shore region is moderately to heavily developed (Hapke and others, 2011); coastal engineering structures are relatively common and include jetties and breakwaters at harbor entrances, scattered groin fields, and long stretches of rip rap and seawalls.

Long-term rates of shoreline change for the South Shore were calculated for 3,479 transects along approximately $198 \mathrm{~km}$ (123 miles) of shoreline. The maximum erosion rate $(-3.0 \pm 0.5 \mathrm{~m} / \mathrm{yr})$ was measured along a highly dynamic spit at New Inlet at the mouth of Herring River (table 3). The highest accretion rate for the long-term $(2.8 \pm 0.3 \mathrm{~m} / \mathrm{yr})$ was measured on the northern side of the Cape Cod Canal at Scusset Beach, where a 3,000-ft jetty was constructed in the early 1900s. Rate of change calculations in this area include a shoreline delineated in 1861, predating construction of the canal.

Short-term linear regression rates of change for the South Shore region were calculated for 2,665 transects along $198 \mathrm{~km}$ (123 miles) of shoreline. Because of a lack of historical shorelines in this area, not all transects intersected the minimum of three shorelines required to compute linear regression statistics. To supplement gaps in the short-term data, end-point rates were calculated for 820 transects for 1994 to 2008 (fig. 7). The short-term maximum linear regression erosion rate was $-5.5 \pm 2.8 \mathrm{~m} / \mathrm{yr}$, measured on the eastern side of Plymouth Beach, facing Cape Cod Bay. The highest short-term linear regression accretion rate for the region was $5.6 \pm 1.7 \mathrm{~m} / \mathrm{yr}$, at the end of the Plymouth barrier at Plymouth Beach. 


\section{Cape Cod Bay}

The Cape Cod Bay region extends from the Cape Cod Canal in Sandwich to Long Point in Provincetown (fig. 8). The geomorphology of the Cape Cod Bay region includes barrier spits fronting large estuaries, sandy headland beaches, and tall coastal banks composed principally of stratified glacial deposits. The region ranges from sparsely to moderately developed (Hapke and others, 2011). Coastal engineering structures such as seawalls, bulkheads, revetments, jetties and groin fields are abundant, particularly along the eastern portion of the region's coastline.

Long-term rates of shoreline change for Cape Cod Bay are based on 2,303 transects along approximately $129 \mathrm{~km}$ (80 miles) of coastline. The maximum erosion rate $-3.0 \pm 1.2 \mathrm{~m} / \mathrm{yr}$, was measured near the entrance to Herring River, along a narrow barrier connecting the Wellfleet mainland to Great Island. The highest accretion rate $(3.5 \pm 2.1 \mathrm{~m} / \mathrm{yr})$ was measured at Chapin Memorial Beach in Dennis.

Short-term linear regression rates of change for the Cape Cod Bay region were calculated for 1,655 transects along $129 \mathrm{~km}$ (80 miles). Because of the limited number of historical shorelines in this area, not all transects intersected the minimum of three shorelines required to compute short-term linear regression statistics. To supplement gaps in the short-term data, end-point rates were calculated for 654 transects for 1971 to 2009 (fig. 8). The maximum linear regression erosion rate of $-4.2 \pm 3.3 \mathrm{~m} / \mathrm{yr}$ was at Chapin Memorial Beach in Dennis. The maximum linear regression accretion rate of $11.5 \pm 11.2 \mathrm{~m} / \mathrm{yr}$ was located at the end of Sandy Neck, a long barrier spit in Barnstable.

\section{Outer Cape Cod}

The Outer Cape Cod region extends from Long Point in Provincetown to Monomoy Island and contains mostly east-facing Atlantic Ocean shoreline (fig. 9). Outer Cape Cod is sparsely developed (Hapke and others, 2011), and most of the region lies within the boundaries of the Cape Cod National Seashore. There are no coastal engineering structures on the ocean-facing coastline. The geomorphology of the northern end of the region from Provincetown to High Head is a series of welded spits capped by a large, stable dune field. South of High Head, tall, glacially derived coastal banks are fronted by narrow sandy beaches. The southern end of the Outer Cape region is made up principally of barrier islands and spits.

Long-term rates of shoreline change were measured at 2,294 transects along approximately $187 \mathrm{~km}$ (116 miles) of coastline. Long-term rates of shoreline change are more uniform in the north and more variable in the barrier system in the south (fig. 9). The highest long-term erosion and accretion rates were measured in the southern portion of the region, along the dynamic barrier system that extends from Nauset Beach to Monomoy Island. The highest erosion rate was $-7.0 \pm 4.2 \mathrm{~m} / \mathrm{yr}$ on Monomoy Island and the highest accretion rate, $10.0 \pm 9.2 \mathrm{~m} / \mathrm{yr}$ was measured on the backshore of Monomoy Island (facing west in Nantucket Sound). In the north, high accretion rates up to $2.3 \pm 0.9 \mathrm{~m} / \mathrm{yr}$ are found near Race Point Light.

The short-term linear regression rates of change for the Outer Cape Cod region (2,073 transects) are highly variable, especially along the southern barrier system. The highest short-term erosion rate of $17 \pm 10 \mathrm{~m} / \mathrm{yr}$ was located at Monomoy Island near Hammonds Bend. The highest accretion rate $(42.6 \pm 41.8 \mathrm{~m} / \mathrm{yr})$ was also measured at Monomoy Island, along the back shore facing Nantucket Sound.

\section{South Cape Cod}

The South Cape Cod region extends along the southern coast of Cape Cod in Nantucket Sound and Vineyard Sound from Stage Harbor Light in Chatham to Nobska Point in Woods Hole (fig. 10). The region is moderately to highly developed (Hapke and others, 2011). Jetties, bulkheads, seawalls, 
revetments, and extensive groin fields are present throughout much of the region. The geomorphology of this region is predominantly sandy headland beaches and small barrier systems fronting lagoons or ponds and well developed wetlands.

Long-term rates of shoreline change were measured at 1,558 transects along approximately $91 \mathrm{~km}$ (57 miles) of coastline. The highest erosion rate $(-4.3 \pm 3.3 \mathrm{~m} / \mathrm{yr})$ was measured at Cockle Cove Beach in Chatham, east of the entrance to Mill Creek. The beach at this location is backed by seawalls and is adjacent to a jetty system that impedes the transport of sediment to the beach. The maximum long-term accretion rate is $3.3 \pm 2.1 \mathrm{~m} / \mathrm{yr}$ at Davis Beach on the updrift side of a jetty located at the mouth of Bass River.

Short-term linear regression rates of shoreline change were calculated for 1,459 transects along $91 \mathrm{~km}$ (57 miles) of coastline. The highest erosion rate of $-2.6 \pm 2.5 \mathrm{~m} / \mathrm{yr}$ was recorded at Cockle Cove Beach, approximately $300 \mathrm{~m}$ east of the location of the maximum long-term erosion rate. The highest accretion rate of $2.3 \pm 1.4 \mathrm{~m} / \mathrm{yr}$ was measured at Sampsons Island near the end of a westward-accreting spit at the entrance to Cotuit Bay.

Long-term and short-term rates of shoreline change in the Cape Cod South region show erosion and accretion trends that appear to be influenced by shoreline stabilization structures such as jetties and groin fields. Relatively small beach nourishment projects are also common on the southern shore of Cape Cod and may have also affected the rates of shoreline change.

\section{Buzzards Bay}

The Buzzards Bay region extends from Nobska Point in Woods Hole to Westport at the Massachusetts-Rhode Island border (fig. 11). The geomorphology of this region is variable, with narrow beaches often backed by low coastal banks or headlands, salt marshes, and barrier spits. Much of the coastline lies within low-energy bays and coves. The coastline is moderately to highly developed (Hapke and others, 2011), and coastal engineering structures such as groins, breakwaters, seawalls and revetments are abundant. Heavily populated areas such as New Bedford contain stretches of commercial and industrial coastline lined with bulkheads, wharves, and similar structures. Heavily developed areas in the New Bedford region were not included in the shoreline change analysis reported here.

Long-term rates of shoreline change in the Buzzards Bay region were computed at 5,026 transects along $298 \mathrm{~km}$ (185 miles) of coastline. The maximum long-term erosion rate for the region $(-1.0 \pm 0.5 \mathrm{~m} / \mathrm{yr})$ was measured near an inlet at the southwestern end of Mattapoisett Neck. The highest accretion rate of $2.1 \pm 1.5 \mathrm{~m} / \mathrm{yr}$ was measured at a narrow sandy beach connecting Great Neck and Stony Point Dike in Wareham.

Short-term linear regression rates were calculated for 4,564 transects. The highest erosion rate was $-1.7 \pm 1.7 \mathrm{~m} / \mathrm{yr}$, at Demarest Lloyd State Park near the mouth of the Slocum River in South Dartmouth. The maximum accretion rate of $2.3 \pm 0.3 \mathrm{~m} / \mathrm{yr}$ was measured along a northward-accreting spit west of Taylor Point.

\section{Elizabeth Islands}

The Elizabeth Islands region consists of a chain of small islands extending southwestward from the southwestern coast of Cape Cod and faces Buzzards Bay to the north and Vineyard Sound to the south (fig. 12). The islands are sparsely developed (Hapke and others, 2011), and with the exception of Cuttyhunk Island, the coastline has few coastal engineering structures. Cuttyhunk Island has a small village and is a popular tourist destination. The geomorphology of the islands is predominantly glacial coastal banks and narrow beaches scattered with coarse, often boulder-sized material. There are a few 
small barrier spits connecting islands and extending across the entrance to small lagoons, most of which are located on Cuttyhunk Island.

Long-term rates of shoreline change for the Elizabeth Islands were computed for 1,785 transects covering $114 \mathrm{~km}$ (71 miles). The highest long-term erosion rate $(-1.2 \pm 0.7 \mathrm{~m} / \mathrm{yr})$ is located on the shore of a small lagoon in Nonamesset Island. The highest long-term accretion rate is $1.1 \pm 0.4 \mathrm{~m} / \mathrm{yr}$, on the updrift side of the Cuttyhunk Harbor jetty.

Short-term rates of shoreline change for the Elizabeth Islands were measured for 1,783 transects along $114 \mathrm{~km}$ (71 miles) of shoreline using the end-point method between 1994 and 2009 due to the lack of historical shorelines from the $1970 \mathrm{~s}$ in the region. The maximum short-term erosion rate $(-3.8 \mathrm{~m} / \mathrm{yr})$ was at Nonamesset Island, and the maximum short-term accretion rate $(1.7 \mathrm{~m} / \mathrm{yr}) \mathrm{was}$ measured at Cuttyhunk Island (table 3 ).

\section{Martha's Vineyard}

The Martha's Vineyard region consists of Martha's Vineyard Island and Nomans Land (fig. 13). The coastal geomorphology of the region includes barrier and headland beaches as well as tall coastal banks composed of mostly stratified glacial deposits. The open coastline of Martha's Vineyard is sparsely to moderately developed (Hapke and others, 2011). The more populated areas such as Edgartown are on the Nantucket and Vineyard Sounds side of the island in the north. There are a few small, isolated coastal engineering structures (principally groins and seawalls) in this area. The southern coast of Martha's Vineyard faces the Atlantic Ocean and is subject to highly variable rates of shoreline change due to exposure to the open ocean.

Long-term rates of shoreline change were calculated for 2,579 transects along $169 \mathrm{~km}$ (105 miles) of shoreline. The maximum erosion rate $(-5.0 \pm 3.1 \mathrm{~m} / \mathrm{yr})$ was measured near the inlet at Norton Point, a narrow ocean-facing barrier fronting Katama Bay (fig. 13). This high erosion rate and associated confidence interval is partly attributed to the reformation of the Katama Bay Inlet in the mid2000s and northward migration of the barrier at the ends of the spit. For the long-term, the Atlantic Ocean-facing side of Martha's Vineyard, including Norton Point and Lucy Vincent Beach, is highly erosional; the average rate of change measured from Wasque Point to Squibnocket Point is $-1.7 \pm 0.4 \mathrm{~m} / \mathrm{yr}$. The maximum accretion rate was $1.9 \pm 1.3 \mathrm{~m} / \mathrm{yr}$, located near Edgartown Light in Edgartown Harbor.

Short-term rates of shoreline change for Martha's Vineyard were measured using linear regression at 1,878 transects over $132 \mathrm{~km}$ (82 miles) of shoreline. Due to a lack of historical shorelines for the last 30 years, end-point rates for 1994 to 2009 were calculated at 143 transects to supplement the gaps in the linear regression data (fig. 13). The maximum short-term linear regression erosion rate, located at Norton Point, was $-5.7 \pm 2.4 \mathrm{~m} / \mathrm{yr}$, near Wasque Point. The average short-term rate of change for the southern shore of Martha's Vineyard (from Wasque Point to Gay Head) was $-1 \pm 2.6$ m/yr, which is not statistically significant and reflects high short-term variability in the shoreline position here. The maximum short-term linear regression accretion rate of $3.7 \pm 3.7 \mathrm{~m} / \mathrm{yr}$ was located at East Beach north of Wasque Point.

\section{Nantucket}

The Nantucket region includes Nantucket, Tuckernuck, and Muskeget Islands and lies partially within Nantucket Sound and the Atlantic Ocean (fig. 14). Similar to Martha's Vineyard, the geomorphology of the region consists of barrier and headland beaches, as well as tall coastal banks made up of mostly stratified glacial deposits. A long, thin sandy barrier connects Great Point to the main portion of Nantucket Island. The Nantucket region is moderately developed (Hapke and others, 2011) 
with the greatest concentration of coastal development along the Siasconset Beach and harbor areas. There are limited coastal engineering structures on the open-ocean coastline of Nantucket Island; however, there are seawalls, bulkheads, riprap, and groins on the developed side of Nantucket Harbor, including an extensive jetty system at the mouth of the harbor. Tuckernuck and Muskeget Islands on the Atlantic Ocean side both have dynamic barrier spits that are continuously changing orientation.

Long-term rates of shoreline change for the Nantucket region are variable, showing erosion on the Atlantic Ocean-facing southern shore but also high accretion rates, often located at the end of barrier spits. Long-term change rates were calculated at 2,227 transects covering $147 \mathrm{~km}$ (91 miles). The maximum erosion rate $(-7.2 \pm 1.3 \mathrm{~m} / \mathrm{yr})$ was located on a barrier spit at Muskeget Island. High erosion rates occurred also on Tuckernuck Island and the southern shore. The long-term average erosion rate for the southern shore from Tom Nevers Beach to Madaket was $-2.1 \pm 0.5 \mathrm{~m} / \mathrm{yr}$. The highest long-term accretion rate of $4.3 \pm 3.7 \mathrm{~m} / \mathrm{yr}$ occurred on the eastern (Nantucket Sound) side of Muskeget Island.

Short-term shoreline linear regression change rates for the Nantucket region were calculated at 1,983 transects along $119 \mathrm{~km}$ (74 miles). Due to a lack of historical shorelines for the past 30 years, endpoint rates for 1994 to 2009 period were calculated for 248 transects to supplement the gaps in the linear regression data (fig. 14). The maximum short-term linear regression erosion rate $-12.4 \pm 1.5 \mathrm{~m} / \mathrm{yr}$, was measured at Tuckernuck Island. Tom Nevers Beach also had high short-term erosion rates up to $-4.9 \pm 1.5 \mathrm{~m} / \mathrm{yr}$. For the short-term, the average rate of change for the Nantucket southern shore was $-1.2 \pm 2.6 \mathrm{~m} / \mathrm{yr}$, which is not a statistically significant trend and reflects the mobility of this beach system. The short-term maximum linear regression accretion rate of $5.5 \pm 4.6 \mathrm{~m} / \mathrm{yr}$ was located at the end of a spit on Esther Island at the entrance to Madaket Harbor.

\section{Effect of Shorelines From the 1970s and 1994 on Long-term Rates of Shoreline Change}

Here we present the results of an experiment that compares the effect of removing certain data from the analysis of long-term rates of shoreline change. Specifically, we computed long-term rates of change that omitted the shorelines from the 1970s and 1994, which have larger positional uncertainties due to source photography, registration errors, potential influence of storm events, and poor image contrast.

For this analysis, rates of shoreline change and the associated rate uncertainties were computed at individual transects in each of the 10 regions with the full dataset and with the reduced dataset that omits the shorelines from the 1970s and 1994. We then generated regionally averaged rates of change (table 4) for the full (LTw) and the reduced (LTwo) datasets to assess whether any significant changes in rates or uncertainties occurred.

The uncertainty associated with a regionally averaged rate of shoreline change is found from the estimated confidence intervals (CI) associated with the reported change rate at individual transects. The simple arithmetic mean of all CI values is rejected (Hapke and others, 2011) because it assumes no spatial independence of CI values and therefore no cancellation of uncertainty due to random variability between transects. Also, an average-rate CI based on the quadrature addition of CIs (square root of the sum of the squares) is rejected because it assumes complete independence of all CI values (that is, no serial correlation between $\mathrm{CI}$ values at adjacent transects).

An alternative approach in which the CI associated with regionally averaged rates of shoreline change $\left(\overline{E_{s c}} *\right)$, described as a "uncertainty reduced for independent n", is found as:

$$
\overline{E_{s c}} *=\frac{\overline{E_{s c}}}{\sqrt{n^{*}}}
$$


where

$\overline{E_{s c}} \quad$ is the arithmetic mean CI, and

$n^{*} \quad$ is the number of CI data points reduced for their serial (spatial) correlation.

Uncertainty values (table 4) found using equation 1 are generally much smaller than an arithmetic mean CI but larger than a quadrature-averaged CI.

The regionally averaged rates are a convenient way to assess the general characteristics of the LTw and LTwo rates of change in each region. Three principal observations for the regionally averaged rates used here are (1) the rates of change for both LTw and LTwo are essentially the same; (2) including more data slightly reduces the uncertainty of the rate; and (3) the shorelines from the 1970s and 1994 are not outliers with respect to the long-term trend. These observations are true for the regional averages, but may not hold at specific transects.

The regional average long-term change rates for LTw and LTwo are essentially the same for 8 of the 10 regions (table 4). The Boston LTw rate is significant, but the LTwo rate is not. For Outer Cape Cod, the LTw erosion rate is about 75 percent lower than the LTwo rate, but both the LTw and LTwo rates of change are not significantly different from 0 . Including more shoreline data points in this dataset reduces the uncertainty of the regionally averaged rates of shoreline change, which is expected as the number of shorelines increases. This is true for all 10 regions in this report.

This comparison suggests that, for the dataset used here, the shorelines from the 1970s and 1994 are not outliers with respect to the long-term regionally averaged trend. That is, neither the rates nor the uncertainties change substantially when the shorelines from the 1970s and 1994 are included.

The data compared here represent regional averages, which allow a general assessment of whether the shorelines from the 1970s and 1994 influence calculated rates of long-term shoreline change, which they do not do at the regional scale. At individual transects, however, that may not be the case due to a number of factors such as the sources of uncertainty described in this section.

\section{Comparison of Rates of Shoreline Change With Previous Work}

A recent coastal change assessment for the mid-Atlantic and New England (Hapke and others, 2011) used nearly identical shoreline data to the data presented here. The results presented here, however, include more extensive spatial coverage along the coast and a more recently delineated (2007, 2008, or 2009) shoreline. The addition of this shoreline might be expected to decrease the uncertainty in the rate of change estimates.

To compare the long-term rates of shoreline change reported in Hapke and others (2011) and those reported here, we used the long-term rate of change data for the measurement transects from Hapke and others (2011) that were spatially closest (adjacent) to the transects used in this report. The Hapke and others (2011) data cover a much smaller spatial extent than this study (fig. 15) and include principally sandy beaches. The Hapke and others (2011) data are present in portions of 7 of the 10 geographic regions used in this report. Table 5 lists a comparison of the regionally averaged rates of change and rate uncertainties for these regions. The method for computing the regional averages is the same as that described above for the LTw and LTwo rate of change comparison.

There is not a significant difference between the rates found by Hapke and others (2011) and this study (table 5). Interpretations of this finding are that, for regionally averaged rates of change on sandy beaches, adding a shoreline from 2007 through 2009 in the area in the study of Hapke and others (2011) did not result in significant improvement in estimates of the rate of change or its uncertainty, and the newer, additional shoreline added in this study is consistent with the linear trend of the rates (that is, the 
new shoreline is not an outlier) estimated by Hapke and others (2011). These observations, however, may not hold for individual transects.

It is reasonable to expect an improvement (reduction) in rate of change uncertainty by adding a new shoreline. As shown in table 5, however, that is not the case in this study. One explanation is that the shoreline from 2007 through 2009, in fact, is a sufficient outlier relative to a linear trend that it offsets a reduction in rate uncertainty that would be expected by increasing the number of shorelines used in the regression. Another explanation is that for the assumption of linear shoreline behavior, increasing the degrees of freedom (that is, adding more shoreline positions) decreases the rate of change uncertainty, but for more than seven to eight shorelines, this decrease is small. It is likely that the addition of the shoreline from 2007 through 2009 in this study demonstrates this effect.

\section{Examples of Different Types of Shoreline Behavior}

The data presented in this report illustrate a number of different kinds of historical shoreline behavior, including (1) unidirectional shoreline change, (2) fluctuating shoreline position, (3) constrained shoreline position, and (4) anthropogenic shoreline relocation.

Several locations along the Massachusetts coast exhibit unidirectional long-term shoreline movement (that is, continuous erosion or accretion). This behavior can occur in both open-ocean settings as well as sounds and bays. For example, figure 16 depicts a section of the Nantucket southern shore and the location of a representative transect where the rate of shoreline change was measured. The historical shorelines show continuous erosion between 1846 and 2009. The long-term rate of shoreline change for the transect is $-3.5 \pm 0.3 \mathrm{~m} / \mathrm{yr}$. Figure 17 shows a similar history of shoreline change for a barrier beach near Osterville, where the long-term rate of change is $-0.8 \pm 0.2 \mathrm{~m} / \mathrm{yr}$.

Fluctuating shoreline positions are illustrated by a sandy beach in Brewster (fig. 18). The beach is highly mobile, likely reflecting the influence of the adjacent creek inlets on beach erosion and accretion. The long-term rate of change is $0.0 \pm 3.4 \mathrm{~m} / \mathrm{yr}$, which indicates high variability in shoreline position with no significant trend.

A constrained shoreline position is characterized by locations where the shoreline indicator (for example, HWL on a sandy beach) is limited in its ability to move. This can occur when an eroding sandy shoreline moves landward until it encounters a rock outcrop or anthropogenic shoreline structure

such as a seawall or revetment. At that point, the position of the shoreline is constrained. An example is illustrated in figure 19, where the shoreline in Marshfield exhibits historical landward movement, but during the past several decades has been essentially fixed by a seawall constructed in 1965 . Here, the short-term rate of change that postdates the construction of the seawall is $-0.2 \pm 0.6 \mathrm{~m} / \mathrm{yr}$. This rate is not statistically significant and indicates little net shoreline movement.

Carson Beach in Boston is an example of anthropogenic shoreline relocation. Figure 20 shows the position of the shoreline in 1893, which was moved seaward approximately $250 \mathrm{~m}$ by artificially filling this embayment some time before 1938. The shoreline position has been relatively stable since 1938.

\section{Summary}

Shoreline change analysis of the Massachusetts coast was conducted using historical shoreline positions spanning 164 years from 1845 to 2009. The Commonwealth was divided into 10 regions for the purposes of this study. Long- and short-term linear regression rates of shoreline change were calculated for a total of 26,510 transects covering 1,804 kilometers (1,121 miles) of shoreline. End-point rates were calculated in locations where there were insufficient data to use the linear regression method. 
The highest statistically significant long-term rates of change (erosion and accretion) were observed on Nantucket, Outer Cape Cod, and Martha's Vineyard (table 3). The highest long-term erosion rate $(-7.2 \pm 1.3 \mathrm{~m} / \mathrm{yr})$ was observed on Muskeget Island in the Nantucket region. The highest long-term accretion rate $(10 \pm 2.3 \mathrm{~m} / \mathrm{yr})$ was observed on the backshore of Monomoy Island (Outer Cape Cod), in Nantucket Sound. The highest statistically significant short-term rates of change (erosion and accretion) occurred on the North Shore, Outer Cape Cod and Nantucket. The highest short-term erosion rate $(-16.3 \pm 12.8 \mathrm{~m} / \mathrm{yr})$ was observed on the North Shore at Sandy Point. The maximum accretion rate for the Commonwealth $(42.6 \pm 41.8 \mathrm{~m} / \mathrm{yr})$ was observed on Monomoy Island on the Atlantic Ocean side of the barrier.

Long-term rates computed with all the shoreline position data available (1800s through 2009) and a reduced dataset (excluding data from the 1970s and 1994) were regionally averaged using methods described in Hapke and others (2011). The two datasets were compared to determine whether the 1970s and 1994 shorelines (derived from source material with larger positional uncertainties) influenced calculated rates of long-term change (table 4). The regionally averaged rates provided a convenient way to assess the general characteristics of rates of shoreline change computed for both datasets in each region. Results include the following observations: (1) the rates of change for both datasets are essentially the same; (2) including more data slightly reduces the uncertainty of the rate of shoreline change; and (3) the data on the shorelines from the 1970s and 1994 are not outliers with respect to the long-term regionally averaged trend. Neither the rates nor the uncertainties change significantly when the shorelines from the 1970s and 1994 are included. This observation may not hold true at individual transects due to a number of environmental and technical considerations.

A comparison of long-term rates of shoreline change on predominantly sandy, open-ocean facing beaches from this study and Hapke and others (2011) was conducted by regionally averaging long-term data selected from spatially adjacent transects (table 5). Results indicate no significant difference between the rates found by Hapke and others (2011) and those reported here. For regionally averaged rates of change on sandy beaches, we find that adding a shoreline from 2007 through 2009 to the study area in the study by Hapke and others (2011) did not result in significant improvement in estimates of the rate of change or its uncertainty and the newer, additional shoreline added in this study is consistent with the linear trend of the rates estimated by Hapke and others (2011). Possible explanations as to why the addition of a new shoreline did not reduce long-term rate of change uncertainty are that the shoreline from 2007 through 2009 is a sufficient outlier relative to a linear trend that it offsets a reduction in rate uncertainty that would be expected by increasing the number of shorelines used in the regression or that, for the assumption of linear shoreline behavior, increasing the degrees of freedom (that is, adding more shoreline positions) decreases the rate of change uncertainty, but for more than seven to eight shorelines this decrease is small.

It is important to understand trends in shoreline behavior due to the influences of natural forces or anthropogenic effects and how those trends are reflected in shoreline change data. Shoreline trends identified in this study include (1) unidirectional long term shoreline movement, characterized by continuous erosion or accretion, which can occur in both high-energy open ocean settings or low-energy settings (sounds and bays); (2) fluctuating shoreline positions, which are highly mobile shorelines that have undergone both erosion and accretion on a long-term basis; (3) constrained shorelines in which movement of the shoreline indicator (for example, high-water line) is limited by natural or anthropogenic features; and (4) anthropogenic shoreline relocation such as the infilling of embayments for development purposes.

Short-term shoreline change can be characterized by fluctuating (for example, cyclic or episodic) nonlinear behavior. High short-term variability increases the rate uncertainty relative to the linear trend 
assumed in linear regression calculations, which in turn increases the potential for rates of shoreline change that are statistically insignificant. Short-term linear regression rates calculated with fewer shorelines can also result in higher uncertainty. Highly variable rates of shoreline change that are statistically insignificant or show negligible net change over the short term do not necessarily indicate a low potential hazard at that location. For example, shoreline response to storms can result in significant and rapid erosion followed by post-storm recovery or accretion over a relatively short time span (in some cases, days or weeks; List and Farris, 1999). The magnitude of the variability in shoreline position can pose a hazard due to these fluctuations.

\section{References Cited}

Applied Coastal Research and Engineering, Inc., 2006, South Shore historical shoreline change analysis - Hull to the Cape Cod canal, MA: Mashpee, Massachusetts, Applied Coastal Research and Engineering, Inc., 22 p.

Anders, F.J., and Byrnes, M.R., 1991, Accuracy of shoreline change rates as determined from maps and aerial photographs: Shore and Beach, v. 59, no. 1, p. 17-26.

Bertness, M.D., 1991, Zonation of Spartina Patens and Spartina Alterniflora in New England Salt Marsh: Ecology, v. 72, no. 1, p. 138-148.

Boak, E.H., and Turner, I.L., 2005, Shoreline definition and detection-A review: Journal of Coastal Research, v. 21, no. 4, p. 688-703.

Benoit, J.R., 1989, Massachusetts shoreline change project: Boston, Massachusetts Coastal Zone Office, 19 p. plus appendixes.

Crowell, Mark, and Buckley, M.K., 1992, Guidelines and specifications for erosion studies, in Inspiration-Come to the headwaters: Association of State Floodplain Managers, annual conference, 15th, Denver, June 10-14, 1991, Proceedings, p. 321-323.

Crowell, Mark, Leatherman, S.P., and Buckley, M.K., 1991, Historical shoreline change-Error analysis and mapping accuracy: Journal of Coastal Research, v. 7, no. 3, p. 839-852.

Danforth, W.W., and Thieler, E.R., 1992, Digital shoreline analysis system (DSAS) user's guide, version 1.0: U.S. Geological Survey Open-File Report 92-355, 42 p. (Also available at http://pubs.usgs.gov/of/1992/0355/report.pdf.)

Dolan, Robert, Fenster, M.S., and Holme, S.J., 1991, Temporal analysis of shoreline recession and accretion: Journal of Coastal Research, v. 7, no. 3, p. 723-744.

Genz, A.S., Fletcher, C.H., Dunn, R.A., Frazer, L.N., and Rooney, J.J., 2007, The predictive accuracy of shoreline change rate methods and alongshore beach variation on Maui, Hawaii: Journal of Coastal Research, v. 23, no. 1, p. 87-105.

Hapke, C.J., Himmelstoss, E.A., Kratzmann, M.G., List, J.H., and Thieler, E.R., 2011, National assessment of shoreline change; historical shoreline change along the New England and mid-Atlantic coasts: U.S. Geological Survey Open-File Report 2010-1118, 57 p., accessed April 4, 2013, at http://pubs.usgs.gov/of/2010/1118/.

Himmelstoss, E.A., 2009, DSAS 4.0-Installation instructions and user guide, in Thieler, E.R., Himmelstoss, E.A., Zichichi, J.L., and Ergul, Ayhan, eds., The digital shoreline analysis system (DSAS) version 4.0-An ArcGIS extension for calculating shoreline change: U.S. Geological Survey Open-File Report 2008-1278, ver. 4.2, 81 p., accessed April 4, 2013, at http://pubs.usgs.gov/of/2008/1278/.

Himmelstoss, E.A., Kratzmann, Meredith, Hapke, C.J., Thieler, E.R., and List, Jeffrey, 2010, The national assessment of shoreline change-A GIS compilation of vector shorelines and associated 
shoreline change data for the New England and mid-Atlantic coasts: U.S. Geological Survey OpenFile Report 2010-1119, accessed April 4, 2013, at http://pubs.usgs.gov/of/2010/1119/.

Leatherman, S.P., and Clow, J.B., 1983, UMD shoreline mapping project: IEEE Geoscience and Remote Sensing Society Newsletter, v. 22, 17 p., 6 appendixes.

Leatherman, S.P., Douglas, B.C., and Labrecque, J.L., 2003, Sea level and coastal erosion require largescale monitoring: Eos Transactions, v. 84, no. 2, p. 13, 16.

List, J.H., and Farris, A.S., 1999, Large-scale shoreline response to storms and fair weather, in Kraus, N.C. and McDougal, W.G. , eds., Coastal sediments, June 21-23, 1999, Long Island, New York: Reston, Virginia, American Society of Civil Engineers, proceedings, p. 1324-1338.

Moore, L.J., 2000, Shoreline mapping techniques: Journal of Coastal Research, v. 16, no. 1, p. 111-124.

Moore, L.J., Ruggiero, Peter, and List, J.H., 2006, Comparing mean high water and high water line shorelines-Should proxy-datum offsets be incorporated into shoreline change analysis?: Journal of Coastal Research v. 22, no. 4, p. 894-905.

Morton, R.A., 1991, Accurate shoreline mapping-Past, present, and future, in Coastal sediments, June 25-27, 1991, Seattle, Washington: Reston, Va., American Society of Civil Engineers, proceedings, v. 1, p. 997-1010.

Morton, R.A., Miller, T.L., and Moore, L.J., 2004, National assessment of shoreline change-Part 1, historical shoreline changes and associated coastal land loss along the U.S. Gulf of Mexico: U.S. Geological Survey Open-File Report 2004-1043, 42 p., accessed April 4, 2013, at http://pubs.usgs.gov/of/2004/1043/.

O’Connell, J.F., 1997, Historic shoreline change mapping and analysis along the Massachusetts shore: Proceedings of the Tenth Symposium of Coastal and Ocean Management, Coastal Zone'97.

Robertson, W.V., Whitman, Dean, Zhang, Keqi, and Leatherman, S.P., 2004, Mapping shoreline position using airborne laser altimetry: Journal of Coastal Research, v. 20, no. 3, p. 884-892.

Ruggiero, Peter, Kaminsky, G.M., and Gelfenbaum, Guy, 2003, Linking proxy-based and datum-based shorelines on a high-energy coastline-Implications for shoreline change analysis: Journal of Coastal Research, special issue 38, fall, p. 57-82.

Ruggiero, Peter, Kaminsky, G.M., Gelfenbaum, G.R., and Voigt, B., 2005, Seasonal to interannual morphodynamics along a high-energy dissipative littoral cell: Journal of Coastal Research, v. 21 , no. 3, p. 553-578.

Ruggiero, Peter, Komar, P.D., McDougal, W.G., and Beach, R.A., 1996, Extreme water levels, wave runup, and coastal erosion, in Proceedings of the 25th International Coastal Engineering Conference, September 2-6, 1996, Orlando, Florida: American Society of Civil Engineers, p. 2793-2805.

Ruggiero, Peter, Komar, P.S., McDougal, W.G., Marra, J.J., and Beach, R.A., 2001, Wave runup, extreme water levels and the erosion of properties backing beaches: Journal of Coastal Research, $\mathrm{v}$. 17, no. 2, p. 407-419.

Ruggiero, Peter, and List, J.H., 2009, Improving accuracy and statistical reliability of shoreline position and change rate estimates: Journal of Coastal Research, v. 25, no. 5, p. 1069-1081.

Sallenger, A.H., Jr., Krabill, W.B., Swift, R.N., Brock, J., List, J., Hansen, Mark, Holman, R.A., Manizade, S., Sonntag, J., Meredith, A., Morgan, K., Yunkel, J.K., Frederick, E.B., and Stockdon, H., 2003, Evaluation of airborne topographic lidar for quantifying beach changes: Journal of Coastal Research, v. 19, no. 1, p. 125-133.

Smith, G.L., and Zarillo, G.A., 1990, Calculating long-term shoreline recession rates using aerial photographic and beach profiling techniques: Journal of Coastal Research, v. 6, no. 1, p. 111-120.

Stockdon, H.F., Holman, R.A., Howd, P.A., and Sallenger, A.H., 2006, Empirical parameterization of setup, swash, and runup: Coastal Engineering, v. 53 no. 7, p. 573-588. 
Stockdon, H.F., Sallenger, A.H., List, J.H., and Holman, R.A., 2002, Estimation of shoreline position and change using airborne topographic lidar data: Journal of Coastal Research, v. 18, no. 3, p. 502513.

Taylor, J.R., 1997, An introduction to error analysis-The study of uncertainties in physical measurement (2d ed.): Sausalito, California, University Science Books, 327 p.

Thieler, E.R., and Danforth, W.W., 1994, Historical shoreline mapping (I)-Improving techniques and reducing positioning errors: Journal of Coastal Research, v. 10, no. 3, p. 549-563.

Thieler, E.R., Himmelstoss, E.A., Zichichi, J.L., and Ergul, Ayhan, 2009, Digital shoreline analysis system (DSAS) version 4.0-An ArcGIS extension for calculating shoreline change: U.S. Geological Survey Open-File Report 2008-1278, accessed April 4, 2013, at http://pubs.usgs.gov/of/2008/1278/.

Thieler, E.R., O'Connell, J.F., and Schupp, C.A., 2001, The Massachusetts shoreline change project1800s to 1994: USGS Administrative Report to the Massachusetts Office of Coastal Zone Management, Boston, MA, 26 p. + Appendices.

U.S. Army Corps of Engineers, 2010, Wave information studies project documentation: U.S. Army Corps of Engineers, accessed March 26, 2013, at http://wis.usace.army.mil/WIS_Documentation.shtml.

Van Dusen, Charles, 1997, Vector-based shoreline change analysis, in 1997 ESRI User Conference, Proceedings: Environmental Systems Research Institute, Inc., accessed March 26, 2013, at http://proceedings.esri.com/library/userconf/proc97/proc97/abstract/a350.htm.

Weber, K.M., List, J.H., and Morgan, K.L.M., 2005, An operational mean high water datum for determination of shoreline position from topographic lidar data: U.S. Geological Survey Open-File Report 2005-1027, accessed March 26, 2013, at http://pubs.usgs.gov/of/2005/1027/.

Western Carolina University, 2012, Beach nourishment, in Program for the study of developed shorelines (PSDS) database, with a section on Massachusetts: Western Carolina University, accessed September 14, 2012, at http://www.wcu.edu/1038.asp. 


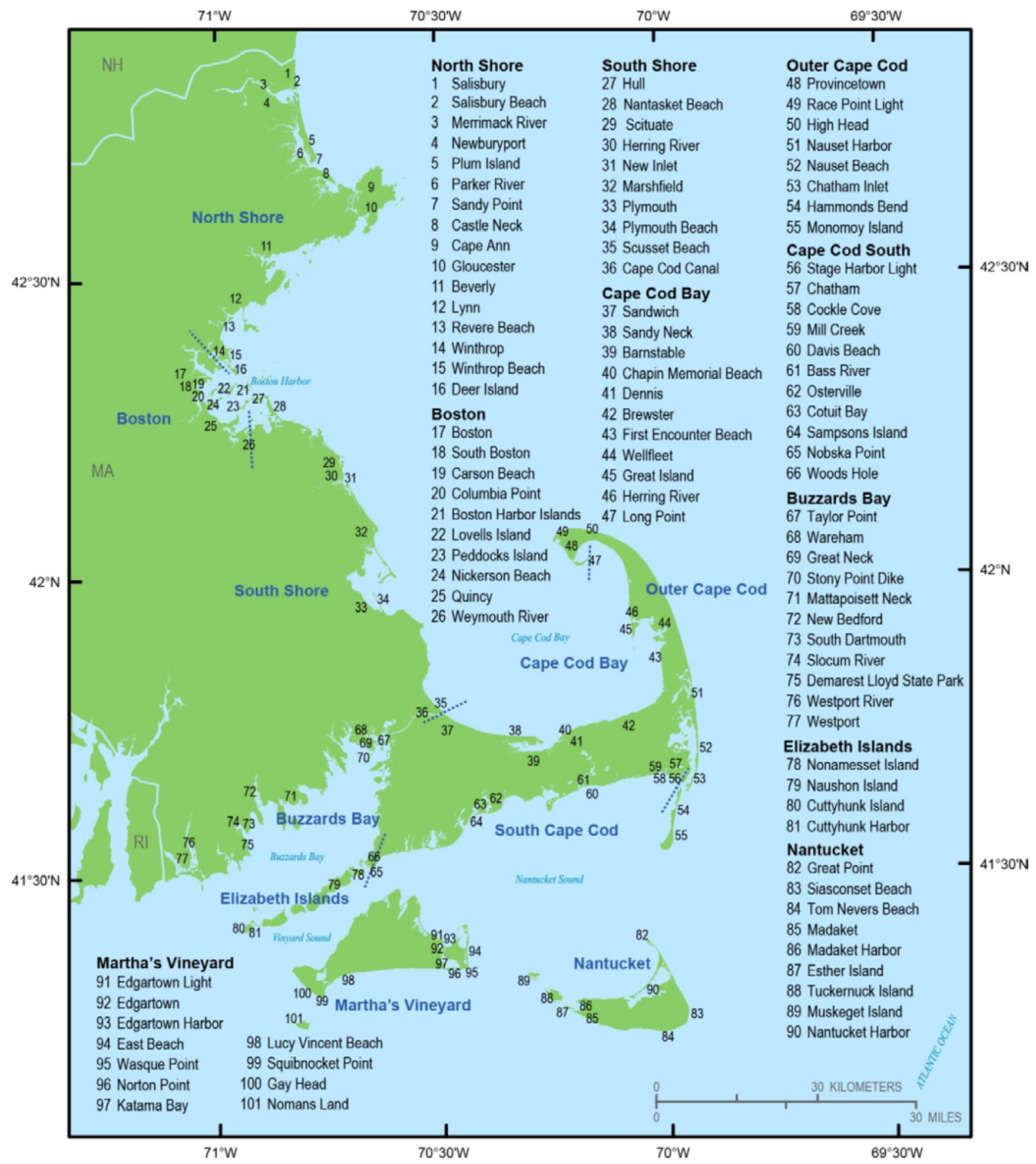

Figure 1. Index map of the Massachusetts coastline, showing place names mentioned on maps and in text. Dashed lines indicate boundaries between regions. 




Figure 2. Map showing the spatial extent of new shoreline data produced for this study. HWL, high water line; $\mathrm{MHW}$, mean high water. 


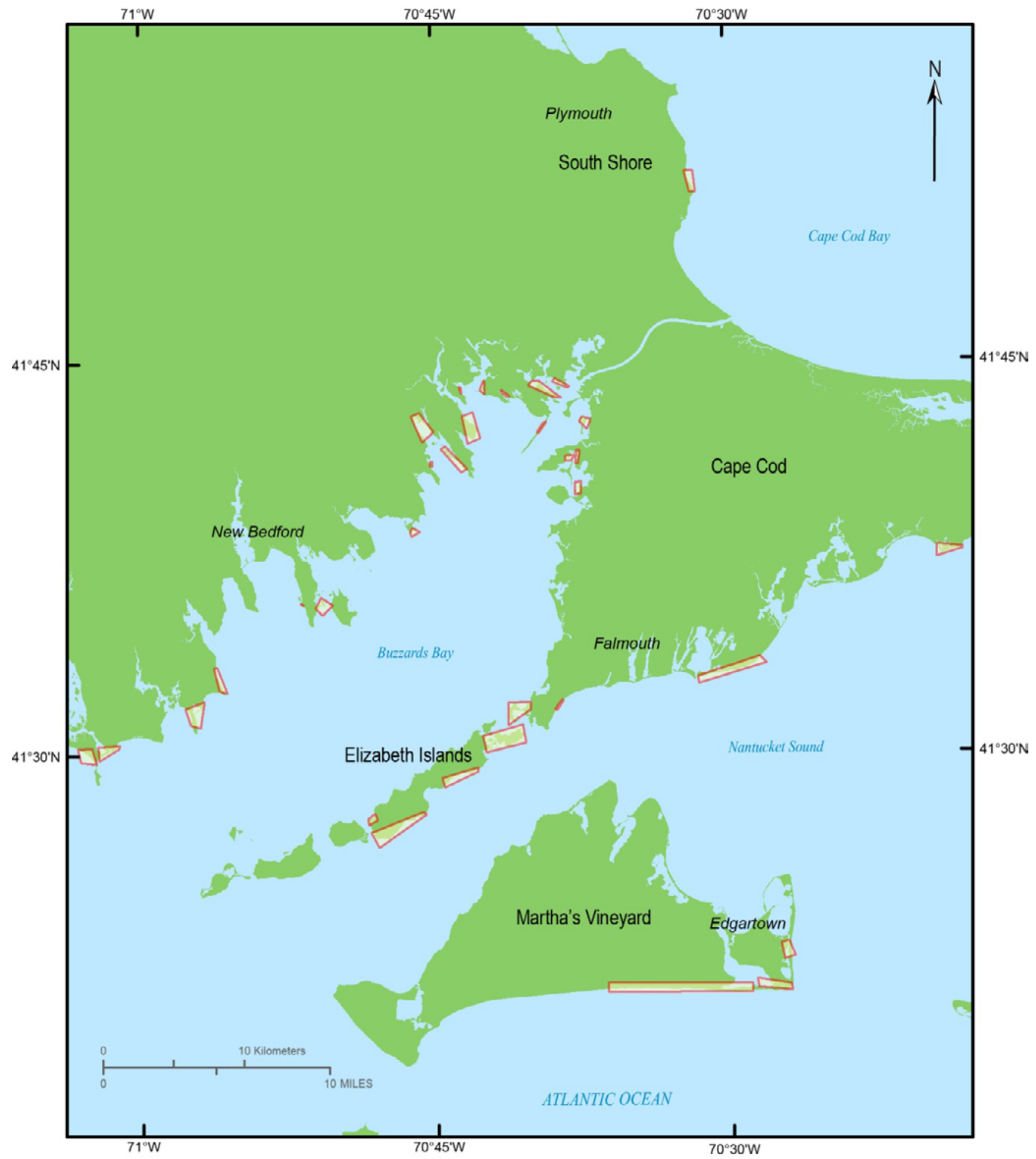

Figure 3. Map showing areas (indicated by polygons) identified as having poor-quality orthophotography from 2009 due principally to image distortions and poor contrast. 


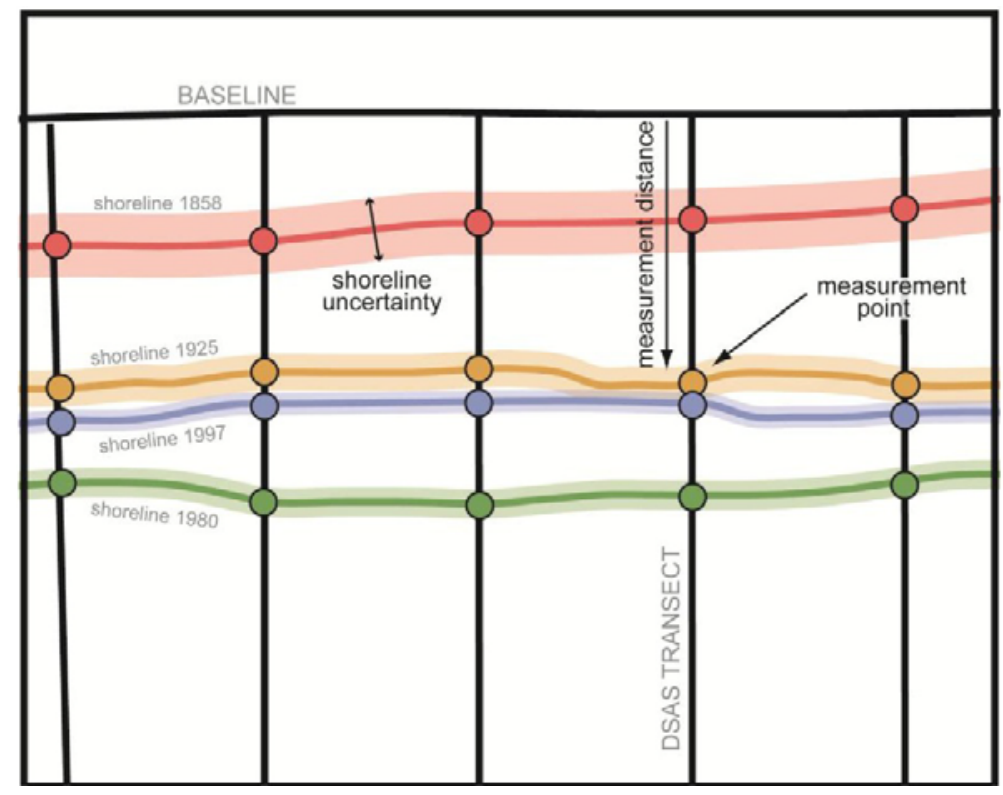

Figure 4. Diagram showing the relation between the measurement baseline, the transects generated by the Digital Shoreline Analysis System (DSAS) software, shoreline measurement points, and shoreline positional uncertainty. From Thieler and others (2009). 


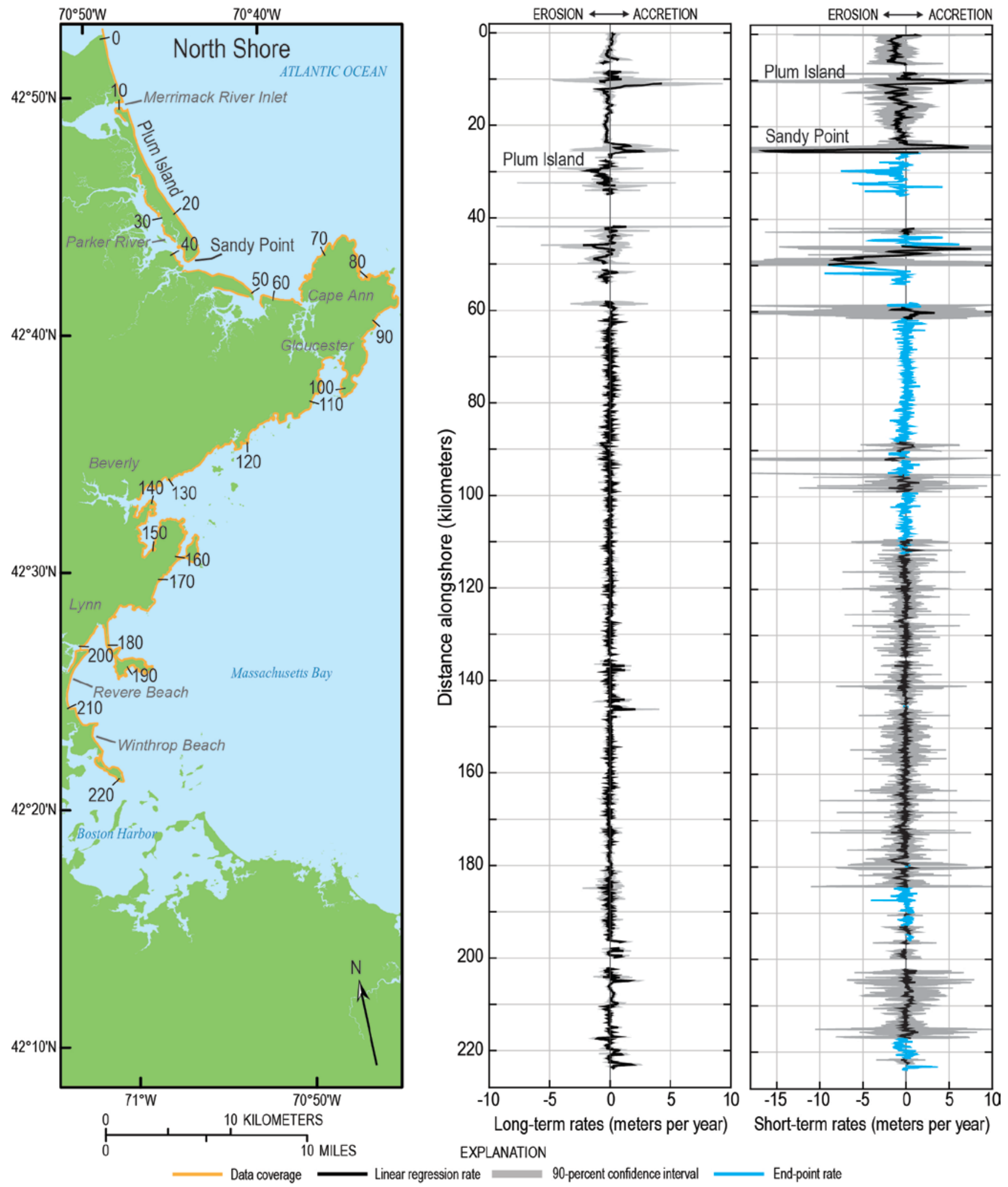

Figure 5. Map and graphs showing long-term linear regression and short-term end-point rates of shoreline change in Massachusetts for the North Shore region. End-point shoreline change rates were calculated for 1994 to 2008. Numbers on the map indicate distance alongshore in the graphs. 

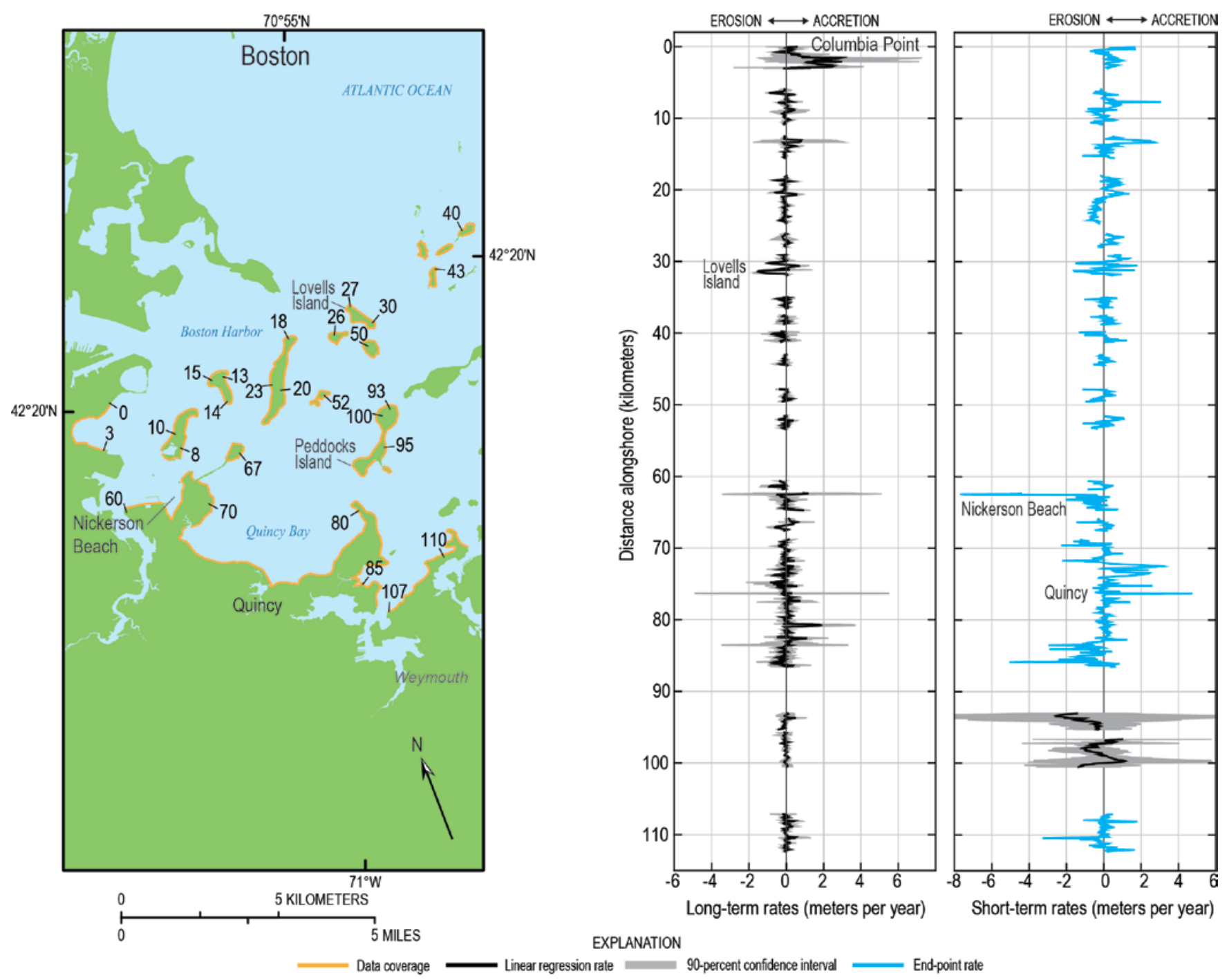

Figure 6. Map and graphs showing long-term linear regression and short-term end-point rates of shoreline change in Massachusetts for the Boston region. End-point shoreline change rates were calculated for 1994 to 2008. Numbers on the map indicate distance alongshore in the graphs. 


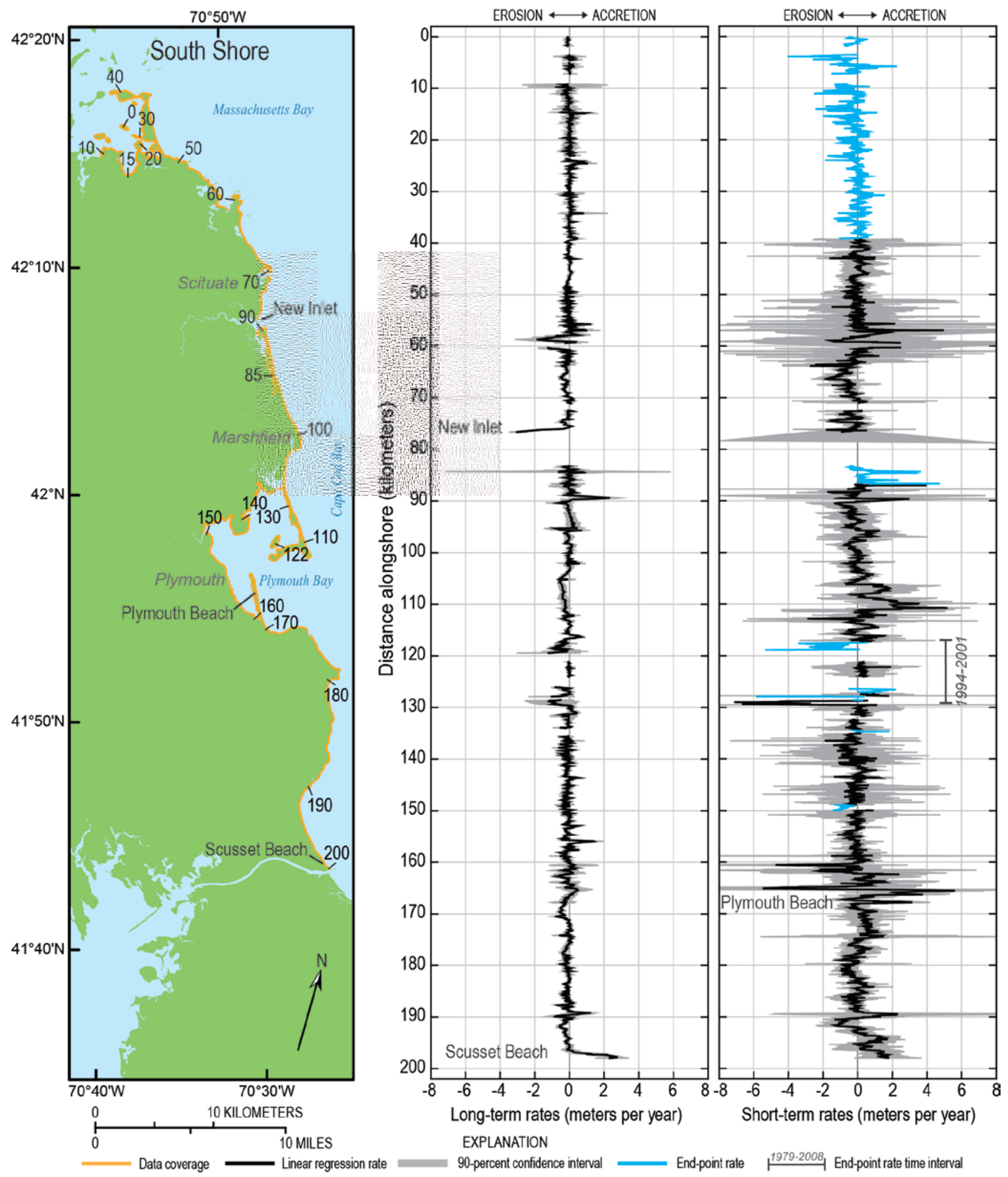

Figure 7. Map and graphs showing long-term linear regression and short-term end-point rates of shoreline change in Massachusetts for the South Shore region. Short-term shoreline rates were calculate for 1994 to 2008, except where otherwise noted on the graph. Numbers on the map indicate distance alongshore in the graphs. 


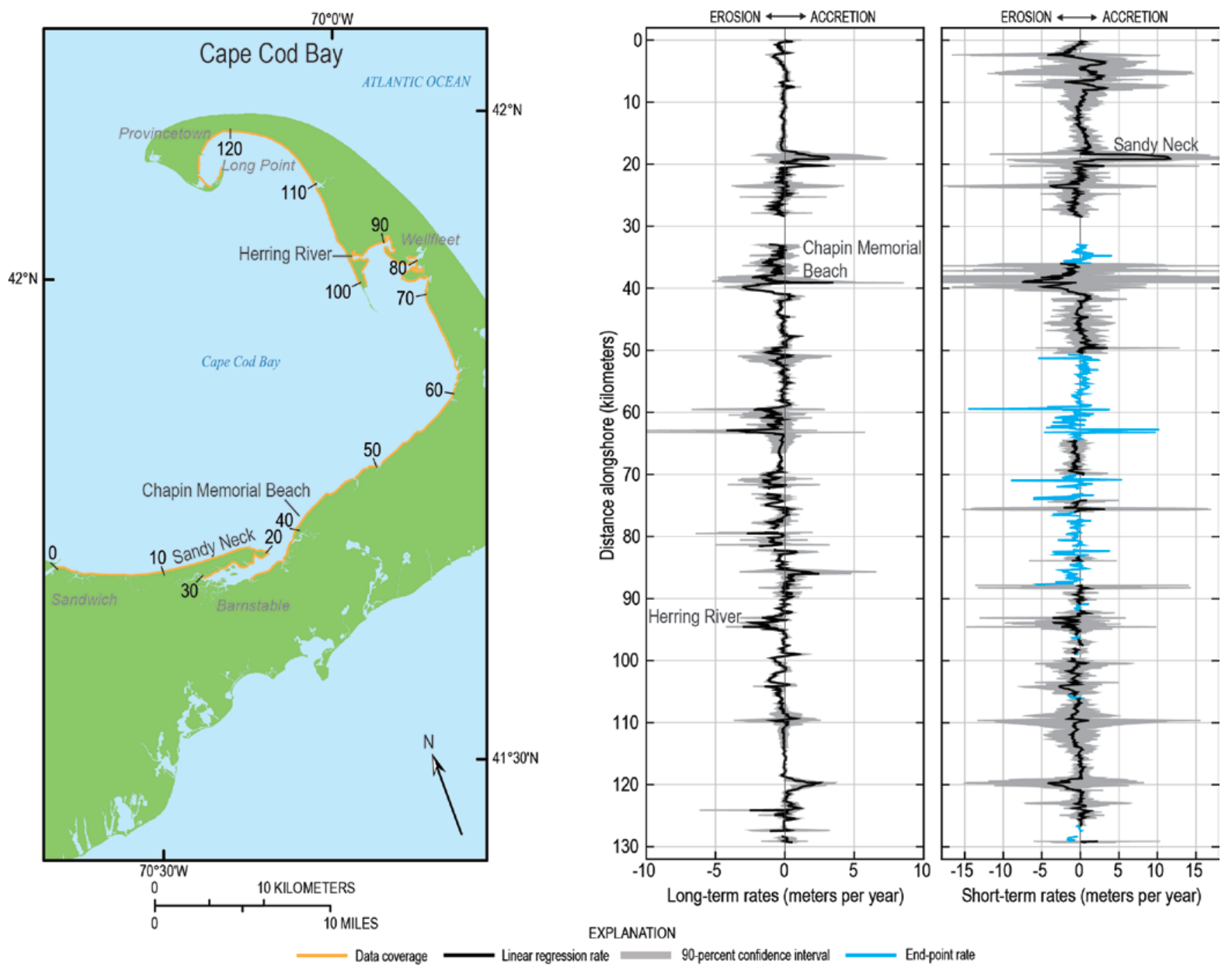

Figure 8. Map and graphs showing long-term linear regression and short-term end-point rates of shoreline change in Massachusetts for the Cape Cod Bay region. End-point shoreline change rates were calculated for 1994 to 2008. Numbers on the map indicate distance alongshore in the graphs. 


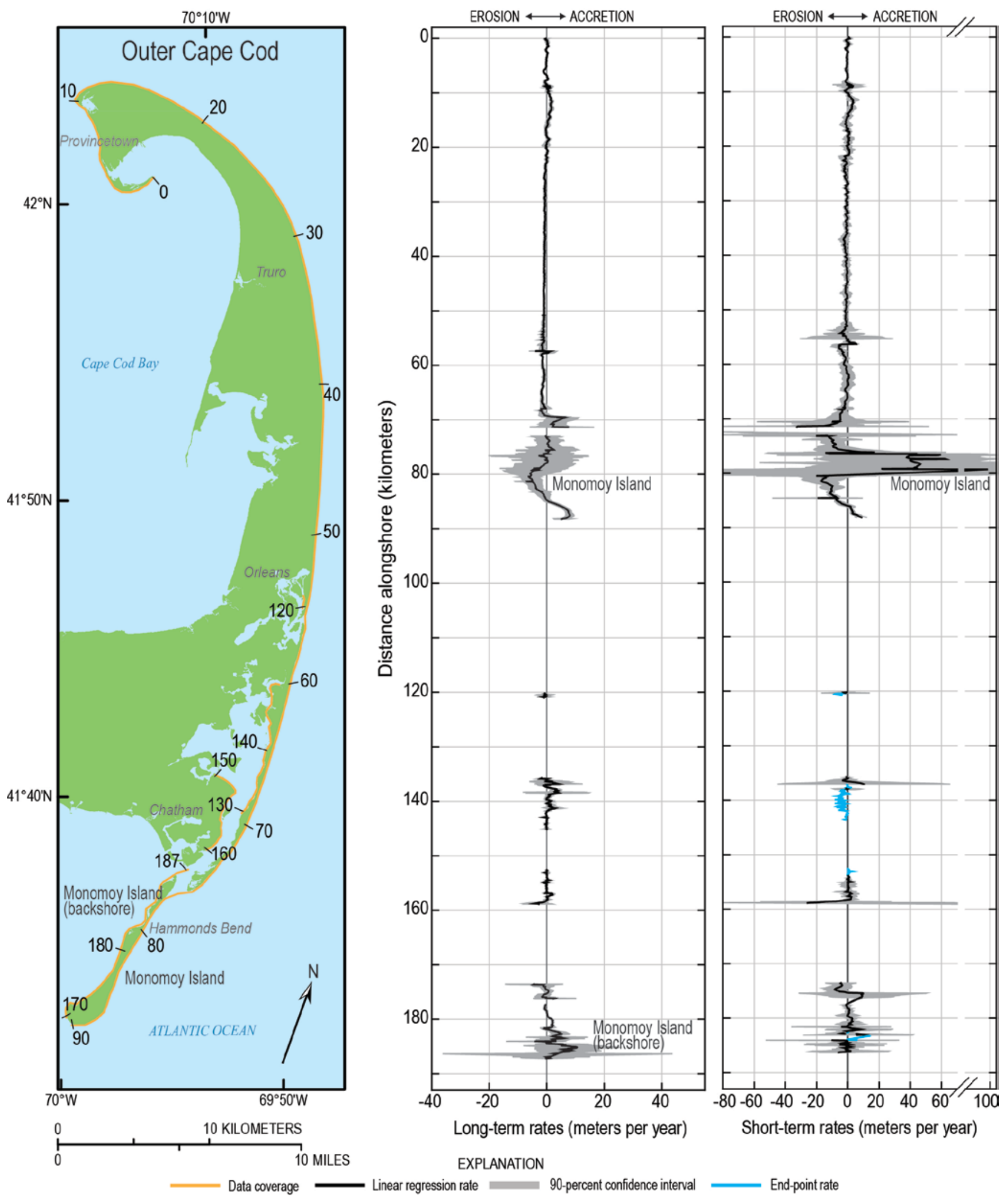

Figure 9. Map and graphs showing long-term linear regression and short-term rates of end-point shoreline change in Massachusetts for the Outer Cape Cod region. End-point shoreline change rates were calculated for 1994 to 2008. Numbers on the map indicate distance alongshore in the graphs. 

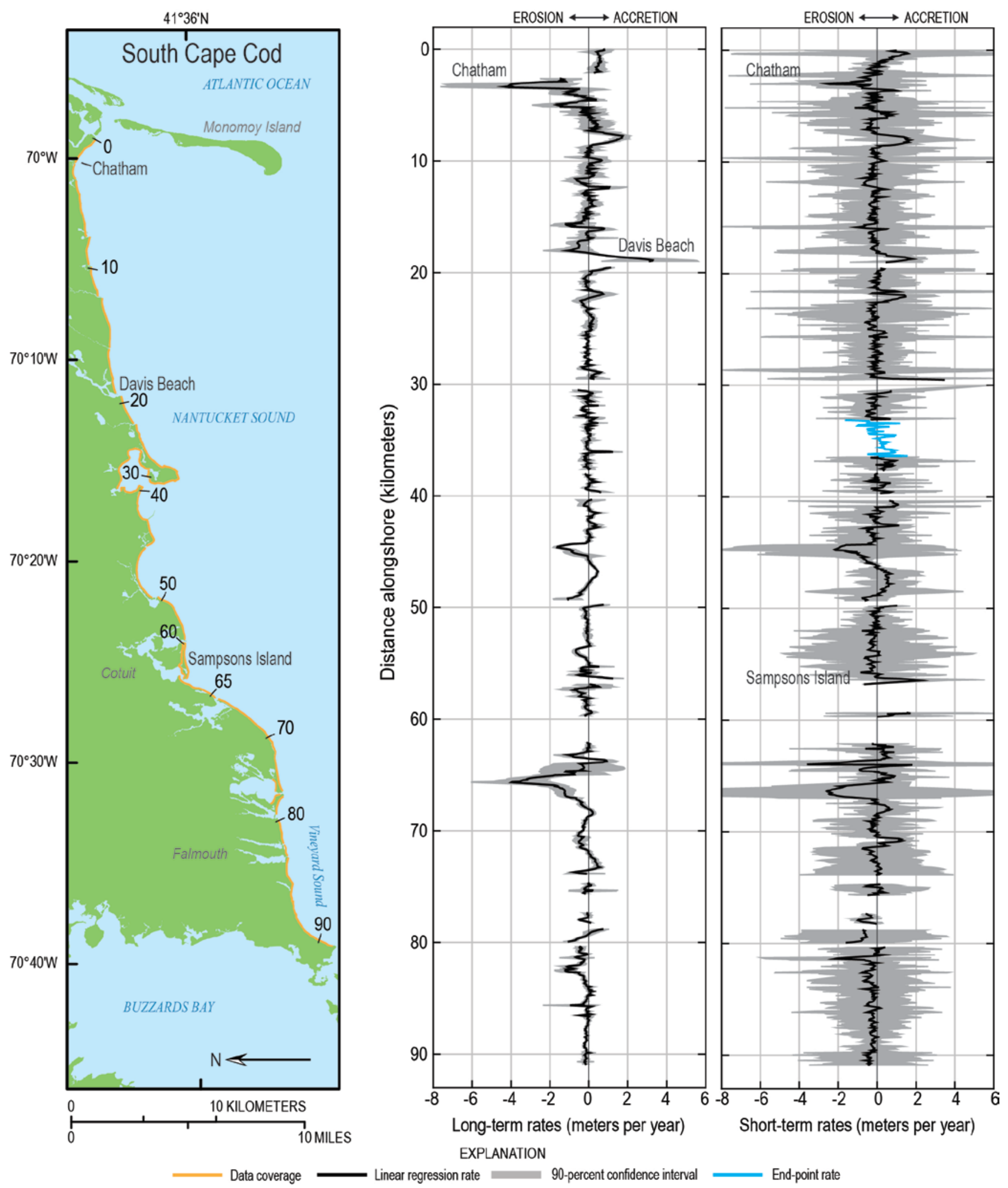

Figure 10. Map and graphs showing long-term linear regression and short-term end-point rates of shoreline change in Massachusetts for the South Cape Cod region. End-point shoreline change rates were calculated for 1994 to 2008. Numbers on the map indicate distance alongshore in the graphs. 


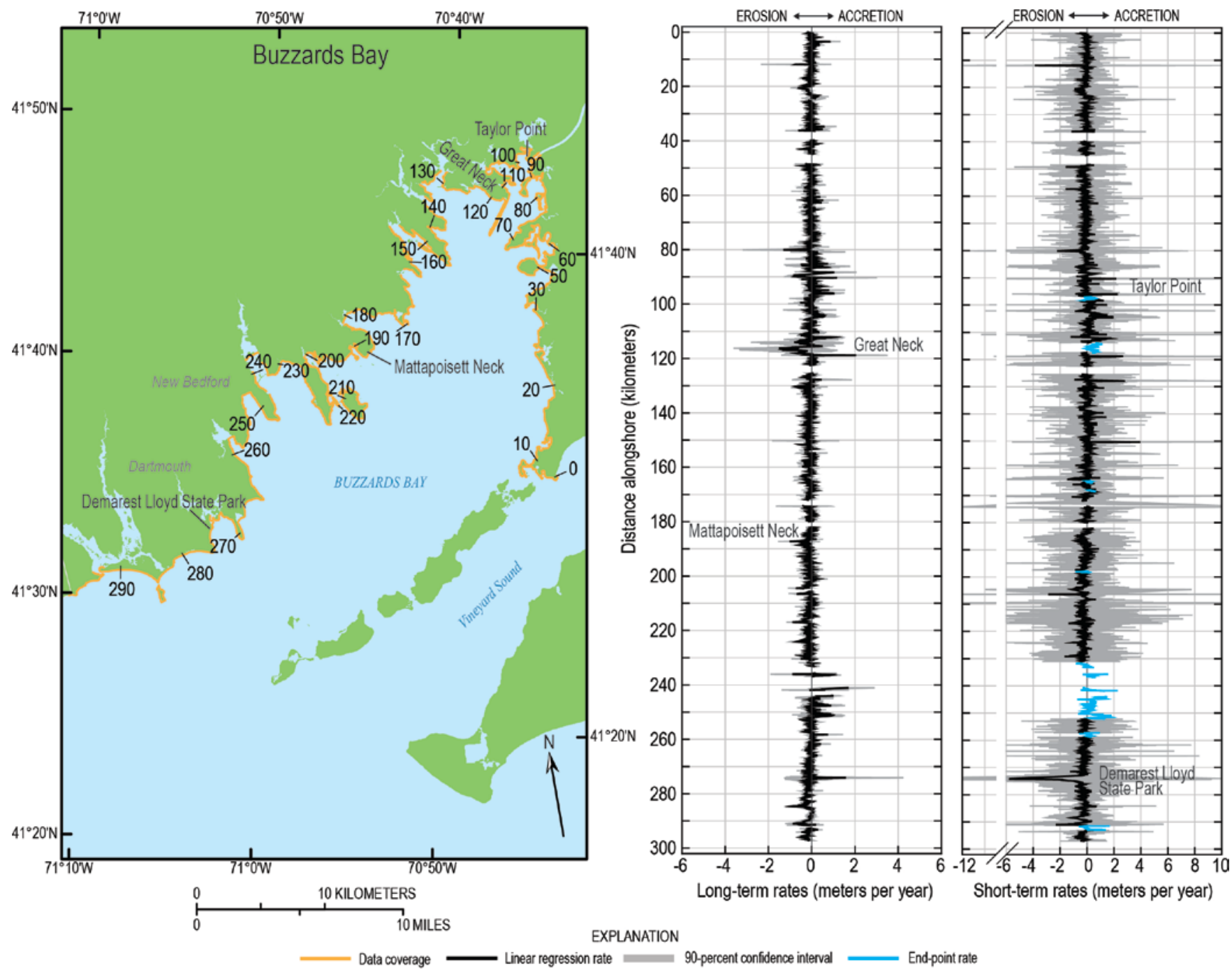

Figure 11. Map and graphs showing long-term linear regression and short-term end-point rates of shoreline change in Massachusetts for the Buzzards Bay region. End-point shoreline change rates were calculated for 1994 to 2008. Numbers on the map indicate distance alongshore in the graphs. 


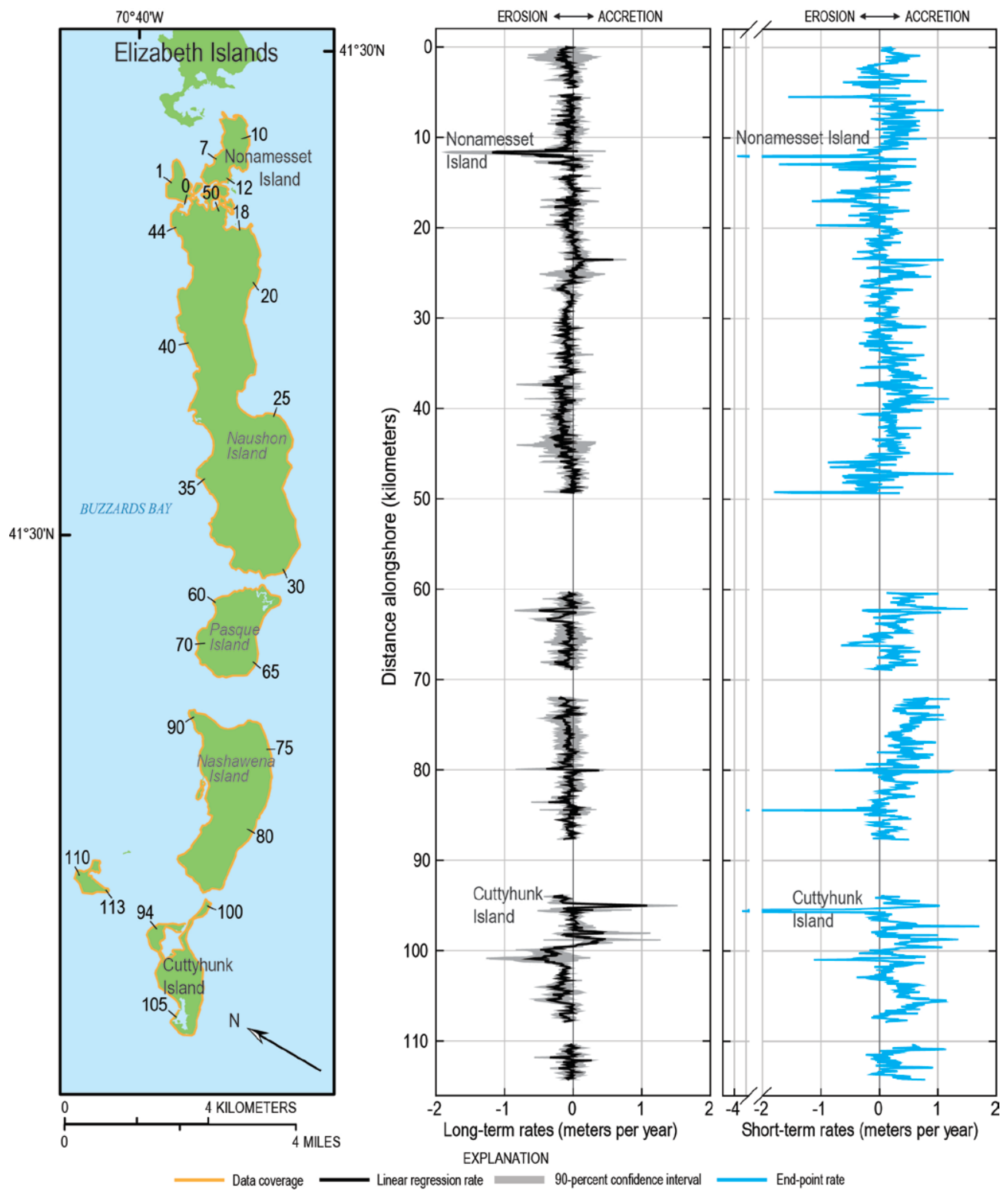

Figure 12. Map and graphs showing long-term linear regression and short-term end-point rates of shoreline change in Massachusetts for the Elizabeth Islands region. End-point shoreline change rates were calculated for 1994 to 2008. Numbers on the map indicate distance alongshore in the graphs. 

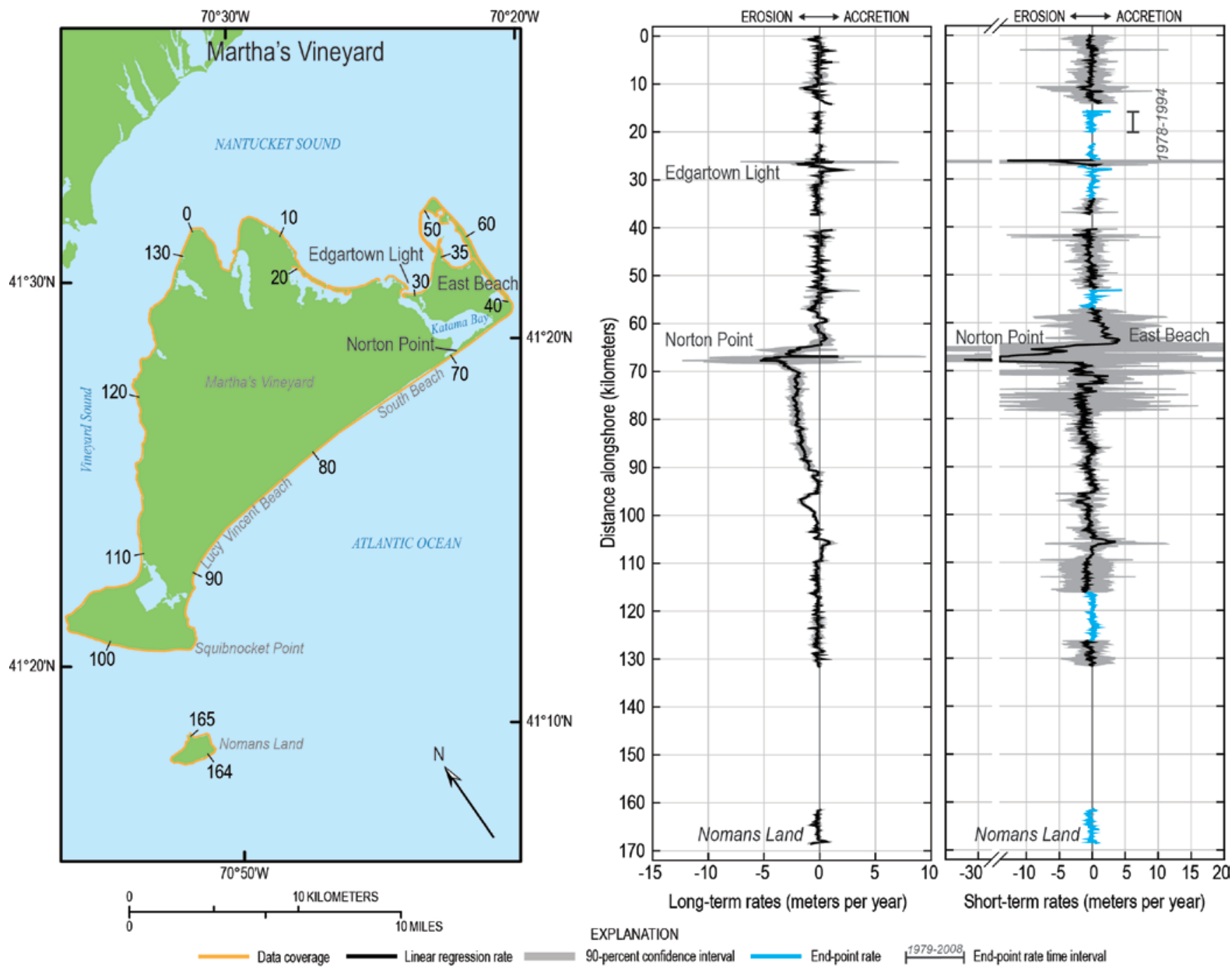

Figure 13. Map and graphs showing long-term linear regression and short-term end-point rates of shoreline change in Massachusetts for the Martha's Vineyard region. End-point shoreline change rates were calculated for 1994 to 2008, except where noted on the graph. Numbers on the map indicate distance alongshore in the graphs. 


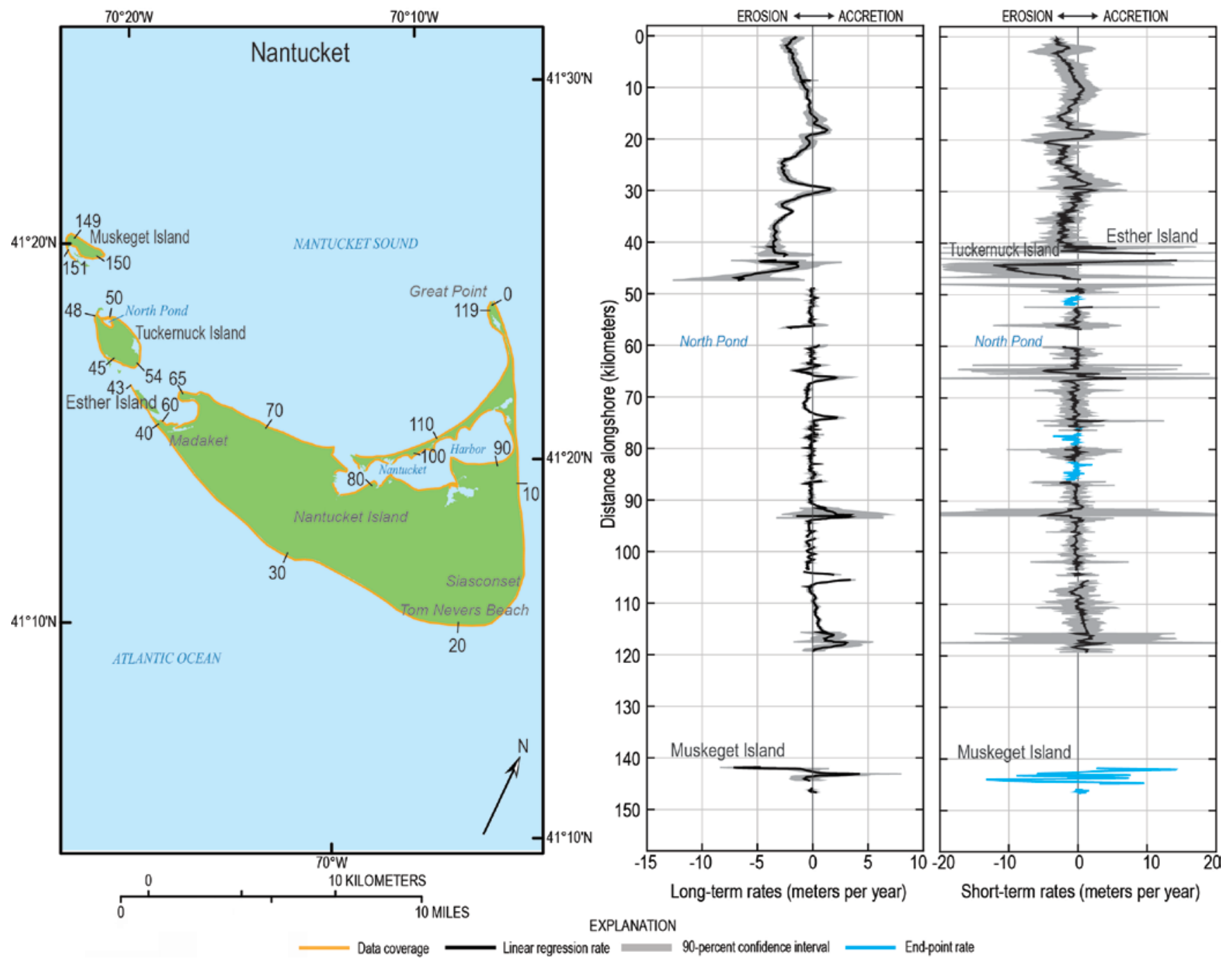

Figure 14. Map and graphs showing long-term linear regression and short-term end-point rates of shoreline change in Massachusetts for the Nantucket region. End-point shoreline change rates were calculated for 1994 to 2008. Numbers on the map indicate distance alongshore in the graphs. 


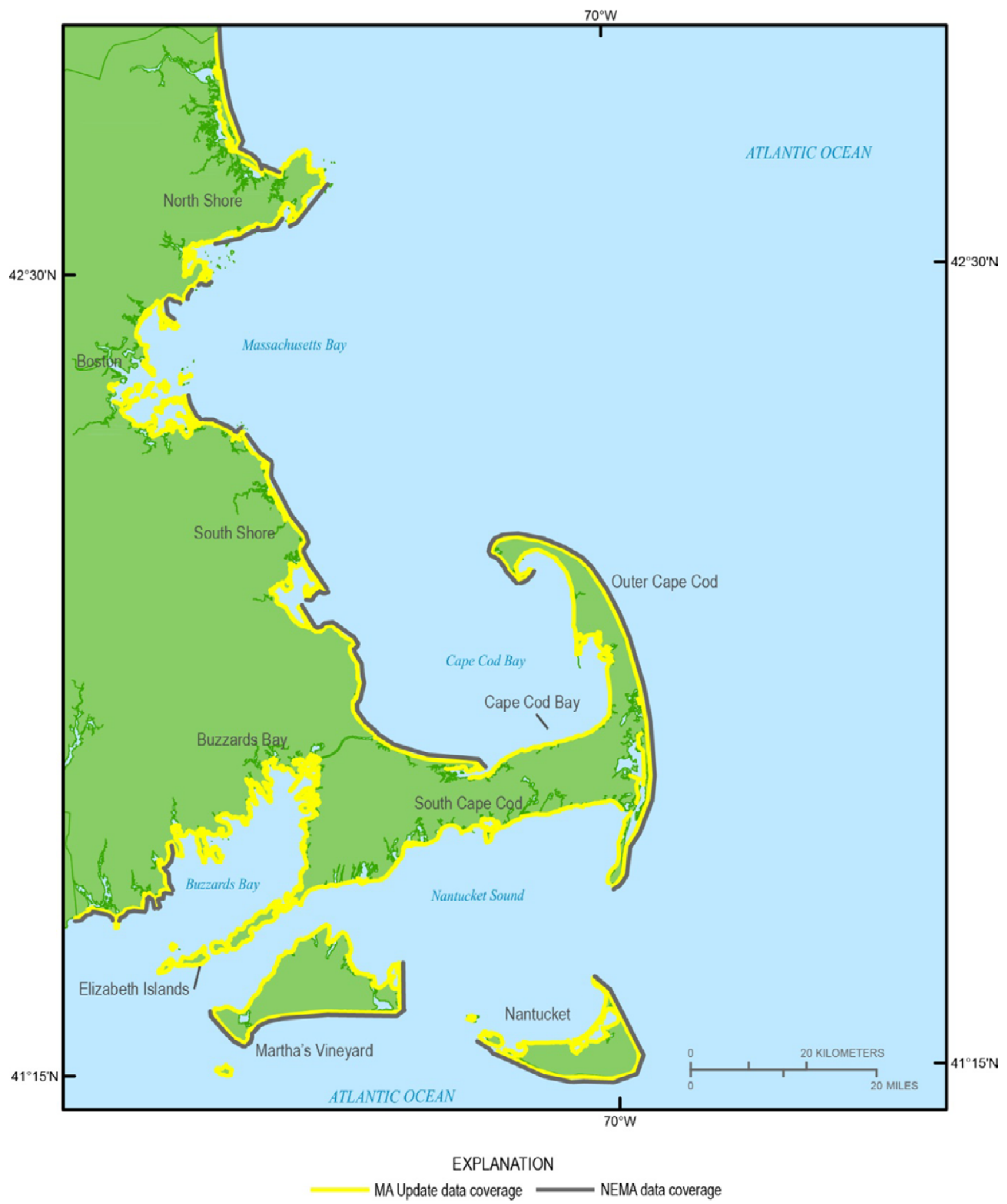

Figure 15. Map showing the spatial extent of historical shoreline data in Massachusetts compared with the data used in the 2010 national assessment of shoreline change (Hapke and others, 2011). NEMA, New England and Mid-Atlantic. 




Figure 16. Orthophotograph and historical shorelines showing a unidirectional long-term trend of shoreline change at transect 769 (yellow line) on the southern coast of Nantucket, Massachusetts. (Image source: Esri World Imagery.) 


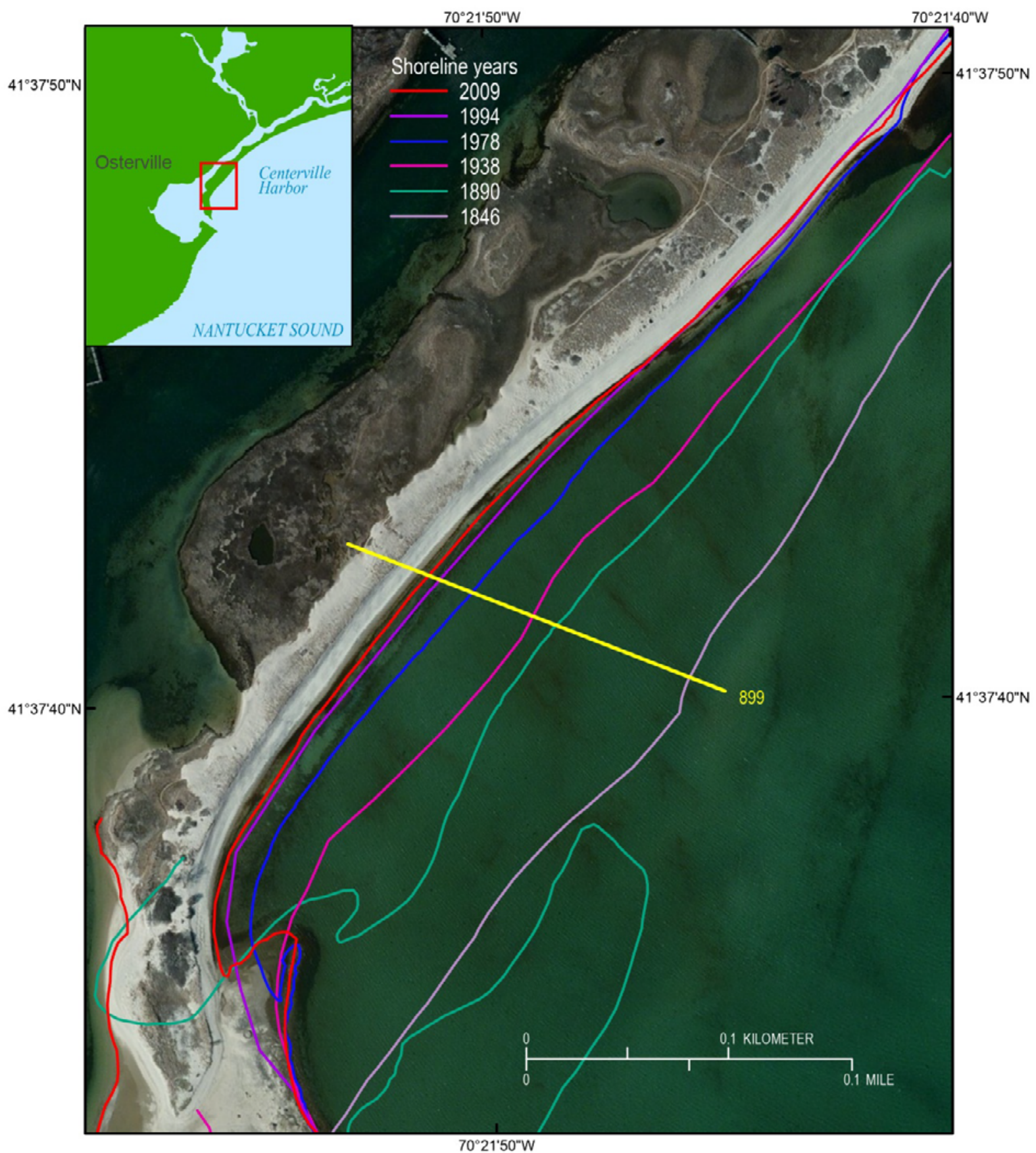

Figure 17. Orthophotograph and historical shorelines showing a unidirectional long-term trend of shoreline change at transect 899 (yellow line) on a barrier spit near Osterville, Massachusetts. (Image source: Esri World Imagery.) 




Figure 18. Orthophotograph and historical shorelines showing a fluctuating history of shoreline change at transect 899 (yellow line) on a sandy beach in Brewster, Massachusetts. (Image source: Esri World Imagery.) 


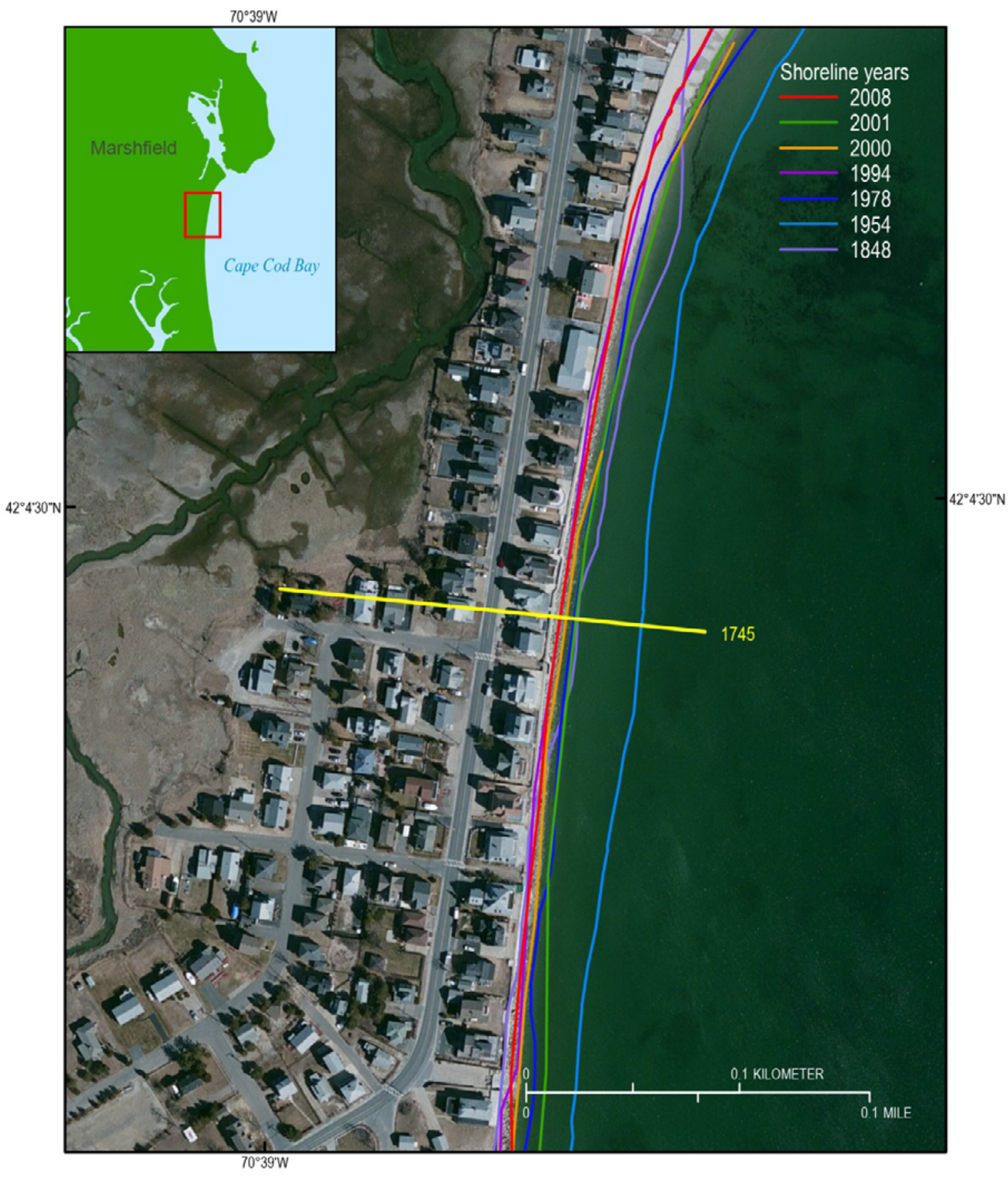

Figure 19. Orthophotograph and historical shorelines showing a landward constraint on shoreline movement due to a seawall at transect 1745 (yellow line) in Marshfield, Massachusetts. (Image source: Esri World Imagery.) 


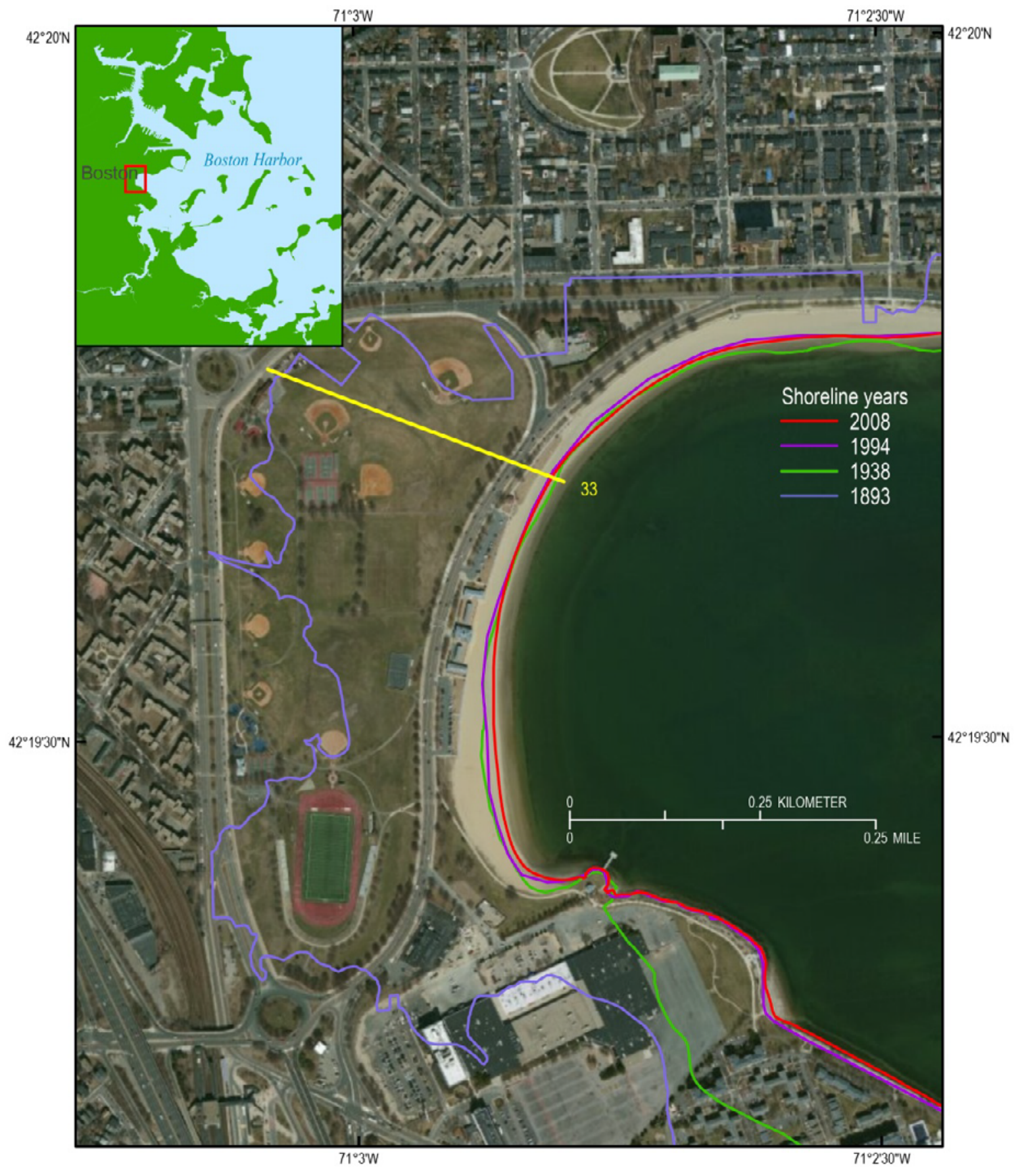

Figure 20. Orthophotograph and historical shorelines showing significant artificial seaward shoreline movement due to human activities at transect 33 (yellow line) at Carson Beach, Massachusetts. (Image source: Esri World Imagery.) 
Table 1. Lengths of shoreline indicators alongshore used to delineate new shorelines in Massachusetts.

[km, kilometers; - , not applicable]

\begin{tabular}{|c|c|c|c|c|}
\hline Region & $\begin{array}{l}\text { High water } \\
\text { line, }{ }^{1} \text { in } \mathrm{km}\end{array}$ & $\begin{array}{l}\text { Operational mean } \\
\text { high water line, }{ }^{2} \text { in } \\
\text { km }\end{array}$ & $\begin{array}{c}\text { Marsh high } \\
\text { water line, in } \\
\text { km }\end{array}$ & $\begin{array}{l}\text { Anthropogenic } \\
\text { features, }{ }^{3} \text { in km }\end{array}$ \\
\hline North Shore & 170 & - & 25 & 77 \\
\hline Greater Boston & 45 & - & 9 & 29 \\
\hline South Shore & 137 & - & 38 & 36 \\
\hline Cape Cod Bay & 138 & - & 50 & 14 \\
\hline Outer Cape Cod & 49 & 85 & 30 & 2 \\
\hline Cape Cod South & 99 & - & 4 & 28 \\
\hline Buzzards Bay & 231 & - & 65 & 61 \\
\hline Elizabeth Islands & 92 & - & 1 & 1 \\
\hline Martha's Vineyard & 134 & - & 6 & 8 \\
\hline Nantucket & 131 & - & 7 & 2 \\
\hline Total & 1,226 & 85 & 85 & 85 \\
\hline
\end{tabular}

${ }^{1}$ Includes previous high-tide line, high-tide wrack line, tonal changes between wet and dry beach material, and algal line on rocky outcrops.

${ }^{2}$ Derived from lidar data.

${ }^{3}$ Includes the interface between manmade features (such as vertical seawalls, bulkheads, groins) and open water.

Table 2. Measurements of uncertainty for the regions used to calculate rates of shoreline change in Massachusetts.

$[-$, not applicable $]$

\begin{tabular}{|c|c|c|c|c|c|c|c|c|}
\hline \multirow[b]{3}{*}{ Measurement uncertainty, in meters } & \multirow{2}{*}{\multicolumn{2}{|c|}{ T-sheets }} & \multirow{3}{*}{$\begin{array}{c}\text { Aerial } \\
\text { photographs, } \\
\text { 1970s to } 1994\end{array}$} & \multicolumn{4}{|c|}{ Orthophotographs } & \multirow{3}{*}{$\begin{array}{l}\text { Lidar, } \\
2000-7\end{array}$} \\
\hline & & & & \multirow{2}{*}{$\begin{array}{c}50 \\
\mathrm{~cm}, \\
200 \\
1\end{array}$} & \multirow[b]{2}{*}{$\begin{array}{c}15 \mathrm{~cm}, \\
2008\end{array}$} & \multicolumn{2}{|c|}{$30 \mathrm{~cm}$} & \\
\hline & $\begin{array}{c}1800 \mathrm{~s} \\
\text { to } \\
1950 \mathrm{~s}\end{array}$ & $\begin{array}{l}1960 \mathrm{~s} \\
\text { to } \\
1980 \mathrm{~s}\end{array}$ & & & & $2008-9$ & $\begin{array}{l}\text { Distorted, } \\
2009\end{array}$ & \\
\hline Georeferencing $\left(U_{g}\right)$ & 4 & 4 & - & - & - & - & - & - \\
\hline Digitizing $\left(U_{d}\right)$ & 1 & 1 & 1 & 1 & 1 & 1 & 1 & - \\
\hline T-sheet survey $\left(U_{t}\right)$ & 10 & 3 & - & - & - & - & - & - \\
\hline Air Photo $\left(U_{a}\right)$ & - & - & 5 & 3 & 0.25 & 2.12 & 4.23 & - \\
\hline $\begin{array}{l}\text { Uncertainty of the high water line } \\
\left(U_{p d}\right)\end{array}$ & 4.3 & 4.3 & 4.3 & 4.3 & 4.3 & 4.3 & 4.3 & - \\
\hline Lidar total position uncertainty $\left(U_{p}\right)$ & - & - & - & - & - & - & - & 1.27 \\
\hline $\begin{array}{l}\text { Total shoreline position } \\
\text { uncertainty }\left(U_{p}\right)\end{array}$ & 11.6 & 6.7 & 6.7 & 5.3 & 4.4 & 4.9 & 6.1 & 1.27 \\
\hline
\end{tabular}


Table 3. Maximum statistically significant rates of shoreline change in Massachusetts.

[max., maximum; $\mathrm{m} / \mathrm{yr}$, meters per year; \pm , plus or minus]

\begin{tabular}{|c|c|c|c|c|c|c|}
\hline \multirow{2}{*}{ Region } & \multicolumn{3}{|c|}{ Long-term rate } & \multicolumn{3}{|c|}{ Short-term rate } \\
\hline & \multicolumn{2}{|c|}{ Rate, in $\mathrm{m} / \mathrm{yr}$} & \multirow{2}{*}{$\begin{array}{l}\text { Location } \\
\text { Maximum erosion }\end{array}$} & \multicolumn{2}{|c|}{ Rate, in $\mathrm{m} / \mathrm{yr}$} & \multirow[t]{2}{*}{ Location } \\
\hline & & & & & & \\
\hline North Shore & -1.7 & \pm 0.7 & Plum Island & -16.3 & \pm 12.8 & Sandy Point \\
\hline Boston & -1.5 & \pm 0.1 & Lovells Island $^{1}$ & -7.7 & & Nickerson Beach \\
\hline South Shore & -3.0 & \pm 0.5 & New Inlet & -5.5 & \pm 2.8 & Plymouth Beach \\
\hline Cape Cod Bay & -3.0 & \pm 1.2 & Entrance to Herring River & -4.2 & \pm 3.3 & $\begin{array}{l}\text { Chapin Memorial } \\
\text { Beach }\end{array}$ \\
\hline Outer Cape Cod & -7.0 & \pm 4.2 & Monomoy Island & -17.0 & \pm 10.0 & Monomoy Island \\
\hline South Cape Cod & -4.3 & \pm 3.3 & Chatham & -2.6 & \pm 2.5 & Chatham \\
\hline Buzzards Bay & -1.0 & \pm 0.5 & Mattapoisett Neck & -1.7 & \pm 1.7 & Demarest Lloyd Beach \\
\hline Elizabeth Islands & -1.2 & \pm 0.7 & Nonamesset Island ${ }^{1}$ & -3.8 & & Nonamesset Island \\
\hline Martha's Vineyard & -5.0 & \pm 3.1 & Norton Point & -5.7 & \pm 2.4 & Norton Point \\
\hline Nantucket & -7.2 & \pm 1.3 & Muskeget Island & -12.4 & \pm 1.5 & Tuckernuck Island \\
\hline \multicolumn{7}{|c|}{ Maximum accretion } \\
\hline North Shore & 2.7 & \pm 2.1 & Sandy Point & 5 & \pm 3.9 & Plum Island \\
\hline Boston & 2.6 & \pm 0.8 & Columbia Point ${ }^{1}$ & 4.7 & & Quincy \\
\hline South Shore & 2.8 & \pm 0.3 & Scusset Beach & 5.6 & \pm 1.7 & Plymouth Beach \\
\hline Cape Cod Bay & 3.5 & \pm 2.1 & Chapin Memorial Beach & 11.5 & \pm 11.2 & Sandy Neck \\
\hline Outer Cape Cod & 10.0 & \pm 9.2 & $\begin{array}{l}\text { Monomoy Island, } \\
\text { backshore }\end{array}$ & 42.6 & \pm 41.8 & Monomoy Island \\
\hline South Cape Cod & 3.3 & \pm 2.1 & Davis Beach & 2.3 & \pm 1.4 & Sampsons Island \\
\hline Buzzards Bay & 2.1 & \pm 1.5 & Great Neck & 2.3 & \pm 0.3 & Taylor Point \\
\hline Elizabeth Islands & 1.1 & \pm 0.4 & Cuttyhunk $^{1}$ & 1.7 & & Cuttyhunk \\
\hline Martha's Vineyard & 1.9 & \pm 1.3 & Edgartown Light & 3.7 & \pm 3.7 & East Beach \\
\hline Nantucket & 4.3 & \pm 3.7 & Muskeget Island & 5.5 & \pm 4.6 & Esther Island \\
\hline
\end{tabular}

${ }^{1}$ End-point rate.

Table 4. Long-term linear regression rates of shoreline change in Massachusetts.

[LTw, includes shorelines from 1970 to 1979 and 1994; LTwo, excludes shorelines from 1970 to 1979 and 1994; m/yr, meters per year; \pm , plus or minus]

\begin{tabular}{|c|c|c|c|c|c|c|c|c|}
\hline \multirow{2}{*}{ Region } & \multicolumn{4}{|c|}{ Long-term regional averages (m/yr) } & \multicolumn{4}{|c|}{ Maximum erosion rates (m/yr) } \\
\hline & \multicolumn{2}{|c|}{ LTw } & \multicolumn{2}{|c|}{ LTwo } & \multicolumn{2}{|c|}{ LTw } & \multicolumn{2}{|c|}{ LTwo } \\
\hline North Shore & -0.01 & \pm 0.05 & -0.01 & \pm 0.05 & -1.3 & \pm 1.2 & -1.2 & \pm 0.4 \\
\hline Boston & 0.03 & \pm 0.03 & 0.03 & \pm 0.11 & -1.5 & \pm 0.1 & -1.5 & \pm 1.0 \\
\hline South Shore & -0.08 & \pm 0.01 & -0.08 & \pm 0.02 & -2.6 & \pm 1.0 & -2.8 & \pm 1.2 \\
\hline Cape Cod Bay & -0.22 & \pm 0.05 & -0.21 & \pm 0.08 & -3.4 & \pm 1.5 & -3.4 & \pm 0.4 \\
\hline Outer Cape Cod & -0.04 & \pm 0.35 & -0.17 & \pm 0.39 & -7.0 & \pm 4.2 & -5.8 & \pm 3.9 \\
\hline South Cape Cod & -0.14 & \pm 0.05 & -0.13 & \pm 0.09 & -4.2 & \pm 1.7 & -4.1 & \pm 2.4 \\
\hline Buzzards Bay & -0.06 & \pm 0.02 & -0.06 & \pm 0.03 & 1.0 & \pm 0.5 & -1.0 & \pm 0.2 \\
\hline Elizabeth Islands & -0.07 & \pm 0.01 & -0.06 & \pm 0.02 & -1.01 & \pm 0.7 & -0.6 & \pm 0.4 \\
\hline Martha's Vineyard & -0.53 & \pm 0.05 & -0.57 & \pm 0.08 & -3.6 & \pm 0.1 & -3.3 & \pm 0.7 \\
\hline Nantucket & -0.66 & \pm 0.07 & -0.67 & \pm 0.11 & -6.8 & \pm 1.5 & -6.9 & \pm 3.4 \\
\hline
\end{tabular}


Table 5. Long-term linear regression rates of shoreline change in Massachusetts calculated by this study and by Hapke and others (2011).

[m/yr, meters per year; \pm , plus or minus]

\begin{tabular}{lcccc}
\hline \multicolumn{1}{c}{ Region } & \multicolumn{2}{c}{$\begin{array}{c}\text { Long-term regional } \\
\text { averages, this report } \\
\text { (m/yr) }\end{array}$} & $\begin{array}{c}\text { Long-term regional } \\
\text { averages for Hapke and } \\
\text { others (2011) (m/yr) }\end{array}$ \\
\hline North Shore & -0.06 & \pm 0.06 & -0.06 & \pm 0.05 \\
South Shore & -0.10 & \pm 0.02 & -0.11 & \pm 0.04 \\
Cape Cod Bay & -0.01 & \pm 0.11 & -0.07 & \pm 0.11 \\
Outer Cape Cod & -0.34 & \pm 0.46 & -0.35 & \pm 0.48 \\
Buzzards Bay & -0.15 & \pm 0.03 & -0.15 & \pm 0.03 \\
Martha's Vineyard & -1.29 & \pm 0.12 & -1.31 & \pm 0.13 \\
Nantucket & -1.57 & \pm 0.13 & -1.53 & \pm 0.13 \\
\hline
\end{tabular}




\section{Appendix 1. Historical Shorelines}

Table 1-1. Sources of historical data on shorelines.

[cm, centimeters; CZM, Massachusetts Office of Coastal Zone Management; m, meters; MassDOT, Massachusetts Department of Transportation; MassGIS, Massachusetts Office of Geographic Information; T-sheets, National Oceanic and Atmospheric Administration topographic map sheets; USGS, U.S. Geological Survey]

\begin{tabular}{llcl}
\hline \multicolumn{1}{c}{ Years } & \multicolumn{1}{c}{ Data source } & Positional uncertainty, in meters & \multicolumn{1}{c}{ Contributor } \\
\hline $1845-1955$ & T-sheet & 11.6 & USGS, CZM \\
$1960-1969$ & T-sheet & 6.7 & USGS, CZM \\
$1970-1979,1982$ & Aerial photography & 6.7 & CZM \\
1994 & 1-m digital orthophotography & 6.7 & CZM \\
2000,2007 & Lidar & 1.27 & USGS \\
2001 & 50-cm digital orthophotography & 5.3 & MassGIS, \\
2008 & 15-cm digital orthophotography & 4.4 & MassDOT \\
2009 & 30-cm digital orthophotography & 4.9 & USGS \\
\hline
\end{tabular}


Prepared by the Pembroke Publishing Service Center.

For more information concerning this report, contact:

\section{Director}

U.S. Geological Survey

Woods Hole Coastal and Marine Science Center

384 Woods Hole Road

Quissett Campus

Woods Hole, MA 02543-1598

WHSC_science_director@usgs.gov

508-548-8700 or 508-457-2200

or visit our Web site at:

http://woodshole.er.usgs.gov/ 
